A Platinum Open Access Journal for Organic Chemistry
Review

Arkivoc 2021, part iv, 241-267

\title{
Nucleobase coupling by Mitsunobu reaction towards nucleoside analogs
}

\author{
Eduardo C. de Sousa and Amélia P. Rauter \\ Centro de Química Estrutural, Faculdade de Ciências, Universidade de Lisboa \\ Ed C8, Piso 5, Campo Grande, 1749-016 Lisboa, Portugal \\ Email:aprauter@fc.ul.pt
}

This paper is dedicated to Prof. Dr. Horst Kunz on the occasion of his $80^{\text {th }}$ anniversary

Received 09-21-2020

Accepted Manuscript 11-29-2020

Published on line 12-20-2020

\section{Abstract}

The coupling of a nucleobase is a key step in the synthesis of most nucleoside analogs, e.g. carbocyclic nucleosides, isonucleosides and acyclic nucleosides. The synthetic strategies for nucleosides based on $N$ glycosylation are not applied when the nucleobase is not linked to the anomeric center. Thus, other methods have been employed, mainly those based on the alkylation of nucleobases. The Mitsunobu reaction, in which a hydroxy group is replaced by a nucleophile, has also been extensively applied, generating a diversity of molecules, including pharmaceuticals and their precursors. In this review the usefulness of this reaction for the coupling of nucleobases to non-anomeric positions of sugars, carbasugars and other homocyclic and linear structures is highlighted and discussed, covering purines and pyrimidines as pronucleophiles.

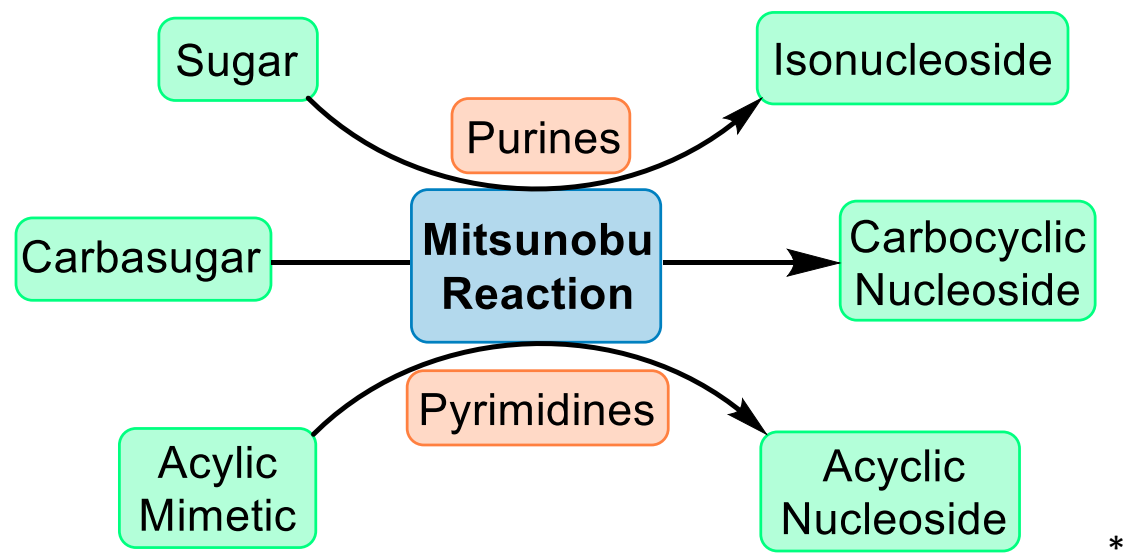

Keywords: Mitsunobu reaction, carbocyclic nucleosides, isonucleosides, acyclic nucleosides, synthesis 


\section{Table of Contents}

1. Introduction

1.1. Nucleoside analogs

1.2. Mitsunobu reaction

2. Nucleobase Coupling

2.1. Reaction conditions in MR and alcohol structure

2.2. Regioselectivity, side reactions and product purification

2.3. MR as an alternative to nucleobase coupling failure

3. Purine Coupling

3.1. Adenine and adenine precursors' coupling

3.2. Guanine precursors' coupling

3.3. Regioselectivity and alkylation of purine amino groups

4. Pyrimidine Coupling

4.1. $\mathrm{N}^{1} / \mathrm{O}-2$ Regioselectivity

5. Coupling of Other Nitrogen Heterocycles

6. Microwave-assisted MR Coupling

7. Conclusions

References

\section{Introduction}

\subsection{Nucleoside analogs}

Nucleosides and nucleotides have been extensively used as prodrugs in antiviral and cancer chemotherapies. Nucleoside analogs comprise often a nucleobase coupled to the anomeric position of a modified carbohydrate moiety and act as inhibitors of nucleic acid synthesis. After entering the cells through specific transporters, they are phosphorylated, leading to the accumulation of nucleotide analogs in cancer or virus-infected cells. These mono-, di- and triphosphorylated nucleotide analogs act by inhibiting intracellular enzymes, or by incorporating the synthesized DNA and RNA, inducing DNA chain elongation termination, apoptosis or mutations in viral progeny. ${ }^{1,2}$ Nucleoside analogs, namely those with carbasugars or acyclic moieties linked to the nucleobase, or with the nucleobase coupled to a non-anomeric position of the carbohydrate (isonucleosides) have been extensively studied. Recently, a comprehensive review was published covering the chemical synthesis of azasugar, thiosugar and selenosugar nucleosides and their anticancer activity. ${ }^{3}$ Both carbocyclic and acyclic nucleosides find application as antiviral drugs, e.g. the carbocyclic nucleoside entecavir and acyclovir, an acyclic nucleoside (Scheme 1). There are also reports of antiviral isonucleosides, e.g. the antiherpetic BMS 181,164, developed by Bristol-Myers Squibb (BMS) ${ }^{4,5}$ but, as far as we know, they do not include the clinically available drugs for the management of viruses. 


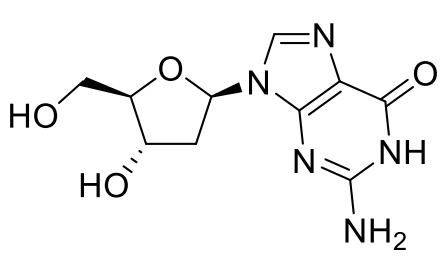

Deoxyguanosine

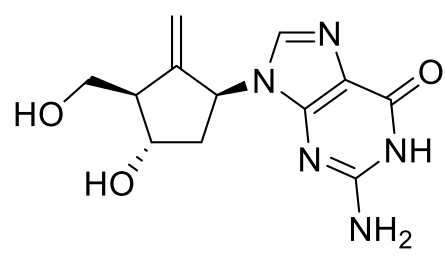

Entecavir<smiles>Nc1nc2c(ncn2COCCO)c(=O)[nH]1</smiles>

Acyclovir

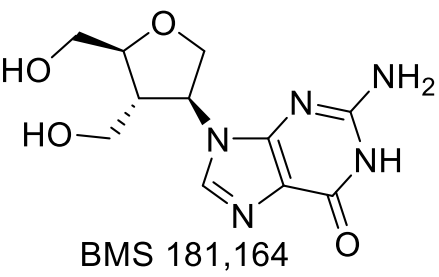

Scheme 1. Structure of deoxyguanosine mimicking antiviral drugs entecavir (carbocyclic nucleoside), acyclovir (acyclic nucleoside) and the isonucleoside BMS 181,164, developed by Bristol Myers and Squibb (BMS).

The absence of a $N$-glycosyl bond, which can potentially increase the stability in a biological environment, ${ }^{6}$ poses a problem: the coupling of the nucleobase to the sugar mimetics or to a non-anomeric position cannot be accomplished by reactions carried out for nucleoside synthesis that take advantage of the specific reactivity of the anomeric center. Therefore, key synthetic strategies must be employed to obtain the nucleoside analog. The most common approaches can be classified into two groups: nucleobase coupling and nucleobase building-up. In the first strategy the desired nucleobase (or a precursor) is coupled directly to the sugar (or sugar mimetics), while in the latter, the nucleobase is constructed from a linear (for pyrimidines) or aromatic (for purines) structure, already linked to the sugar. The coupling of the nucleobase can be achieved by a variety of methods. ${ }^{7,8}$ One of them makes use of the Mitsunobu reaction (MR), as illustrated and discussed in this review for the synthesis of nucleoside analogs.

\subsection{The Mitsunobu reaction}

First reported in $1967,{ }^{9}$ this reaction has a diversity of synthetic applications as described in comprehensive reviews published in $2009{ }^{10}$ and $2015 .{ }^{11} \mathrm{MR}$ conducts to the replacement of the substrate free hydroxy group by a nucleophile, with inversion of configuration when the substrate is chiral, mediated by dialkyl azodicarboxylate and trialkyl- or triarylphosphane. The reaction requires the activation of dialkyl azodicarboxylate with the phosphane leading to the formation of betaine $\mathbf{1}$, which reacts with the pronucleophile $(\mathrm{NuH})$ generating the ionic species 2 . Reaction with the alcohol gives a phosphonium salt and ethyl 2-(propionyloxy)hydrazinecarboxylate (3). The attack of the nucleophile follows a $S_{N} 2$ mechanism to afford the final product and trialkyl- or triarylphosphane oxide, ${ }^{10-12}$ as shown in Scheme 2, for a reaction mediated by diethyl azodicarboxylate (DEAD) and triphenylphosphane. Interestingly, a $\mathrm{S}_{\mathrm{N}} 1$ mechanism can take place, but is very rare and was never reported to occur in nucleobase coupling. ${ }^{10}$ The pronucleophile usually comprises a -OH, -SH or -NHR group, although other groups with a pKa lower than 11 may also react. ${ }^{11}$ The common azodicarboxylates in MR are DEAD and diisopropyl azodicarboxylate (DIAD), di-tert-butyl azodicarboxylate (DBAD) is also used, while triphenylphosphane is, indeed, the most frequently phosphane applied.

Catalytic MRs should also be highlighted, as they overcome MR issues such as poor atom economy, and the formation of stoichiometric phosphane oxide and/or hydrazine by-products. Aiming at reducing to a catalytic amount the azo MR reagent, Toy et al. ${ }^{13,14}$ used iodobenzene diacetate to reoxidize the hydrazine formed, while Hirose et al. ${ }^{15,16}$ described the first MR in which hydrazine is reoxidized in the presence of a catalytic amount of iron phthalocyanine and atmospheric oxygen. The first fully catalytic MR was reported by Buonomo \& Aldrich, ${ }^{17}$ who used catalytic 1-phenylphospholane, employing phenylsilane to recycle the catalyst, integrating it with Taniguchi's azocarboxylate catalytic system. One year later, Hirose et al. ${ }^{18}$ reinvestigated this reaction and in 2016 they reported examples for which the catalytic system in phosphane 
reagent is incompatible with that in the azo reagent. Recently, a fully catalytic redox-free MR has been reported $^{19}$ using (2-hydroxybenzyl)(methyl)(phenyl)phosphane oxide as catalyst. The oxidation state of phosphorus remains +5 all over the reaction, as the mechanism involves the formation of a phosphonium ring with the oxygen of the phenol hydroxy group linked to phosphorus, which is opened by the alcohol. This reaction has been successful for $\mathrm{C}-\mathrm{O}, \mathrm{C}-\mathrm{N}$ and $\mathrm{C}-\mathrm{S}$ bond formation, leads to inversion of configuration, does not involve stoichiometric oxidant nor reductant, and has water as the single by-product. ${ }^{19}$ To the best of our knowledge, catalytic MR reactions have not yet found application for the synthesis of nucleoside analogs.

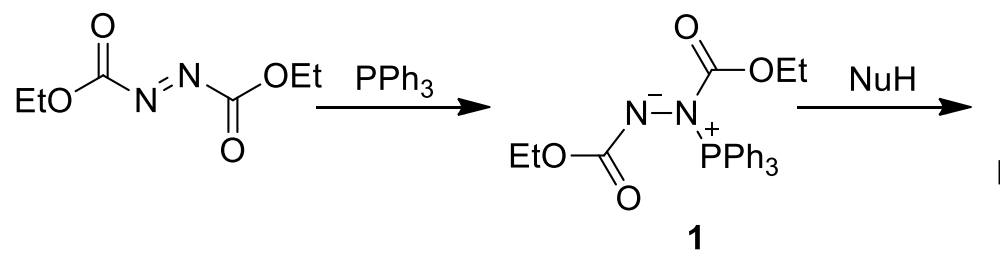

1

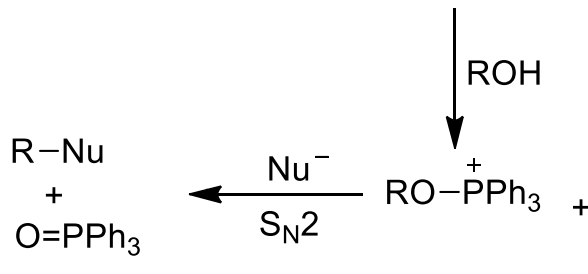<smiles>CCOC(=O)NN([P+]#N)C(=O)OCC</smiles><smiles>CCOC(=O)NNC(=O)OCC</smiles>

3

Scheme 2. Mechanism for the Mitsunobu reaction. ${ }^{12}$

In nucleoside analog synthesis, the nucleobase acts as a pronucleophile and replaces the hydroxy group of the substrate. Therefore, this synthetic strategy is more efficient in a single unprotected hydroxy group, although steric hindrance may affect the reactivity of some hydroxy groups, resulting in regioselectivity. ${ }^{20}$ The nucleobase also has an impact on the outcome of the reaction as further discussed in this review.

MR has seen extensive use for nucleobase alkylation, mostly in the context of drug development, including scale up attempts, namely for the synthesis of the antiviral drug entecavir, in gram ${ }^{21,22}$ and even kilogram ${ }^{23}$ scales. The application of MR in large scale has so far been limited by the complex nature of the resulting reaction mixtures, which makes them difficult to purify. However, the methodologies based on catalytic Mitsunobu reactions seem to solve this issue. ${ }^{19,24}$

\section{Nucleobase Coupling}

The effectiveness of the nucleobase coupling by MR depends on the alcohol precursor, the nucleobase and the reaction conditions, namely the solvent, the temperature and the order in which the reagents are added. ${ }^{25-28}$ The usual yield of a nucleobase coupling reaction through MR is in the $50 \%$ to $80 \%$ range, for carbasugar, other carbohydrates and acyclic substrates, with higher yields being generally obtained with primary alcohols. The low reactivity of the alcohol, a lack of regioselectivity, side reactions and the difficulty in purification of the complex reaction mixture may also compromise reaction yields. ${ }^{29,30}$ Nonetheless, MR is a suitable and unique alternative to some nucleoside analogs that could not be synthesized by the usual 
methodologies and has proven appropriate for the coupling of purines and pyrimidines as described in sections 3 and 4 of this review.

\subsection{Reaction conditions in $M R$ and alcohol structure}

In carbocyclic nucleoside and isonucleoside synthesis the limiting reagent is the alcohol, while for acyclic nucleosides it is common to use an excess of alcohol in relation to the nucleobase. ${ }^{26,28,31-34}$ This excess may have to be handled in different ways, as demonstrated by Lu et al.. ${ }^{31}$ Aiming to overcome low yields caused by alcohol degradation, two successive additions of the non-limiting reagents (alcohol, DIAD and PPh 3 ), separated by 6 hours, were made, resulting in a considerable yield increase. Similar procedures have also been successfully used by other authors. ${ }^{26,34}$

The influence of alcohol structure on reaction yield is clearly demonstrated by Šála et al. ${ }^{35}$ during coupling of 6-chloropurine with bicyclic alcohols 4, 5, 6 and 7 (Scheme 3) via MR protocol. While the yield was higher with a primary alcohol, resulting from less steric hindrance, those for the secondary alcohol substrates were considerably different, with the highest yield obtained for alcohol 5. Lu et al., ${ }^{31}$ Dai et al. ${ }^{32}$ and Fletcher et al. ${ }^{33}$ used tert-butanol as a model tertiary alcohol but no reaction occurred, while the other alcohols screened gave yields in the $80-90 \%$ range, with the nucleobase as the limiting reagent. This was expected as MR reacts mainly via $\mathrm{S}_{\mathrm{N}} 2$ mechanism.

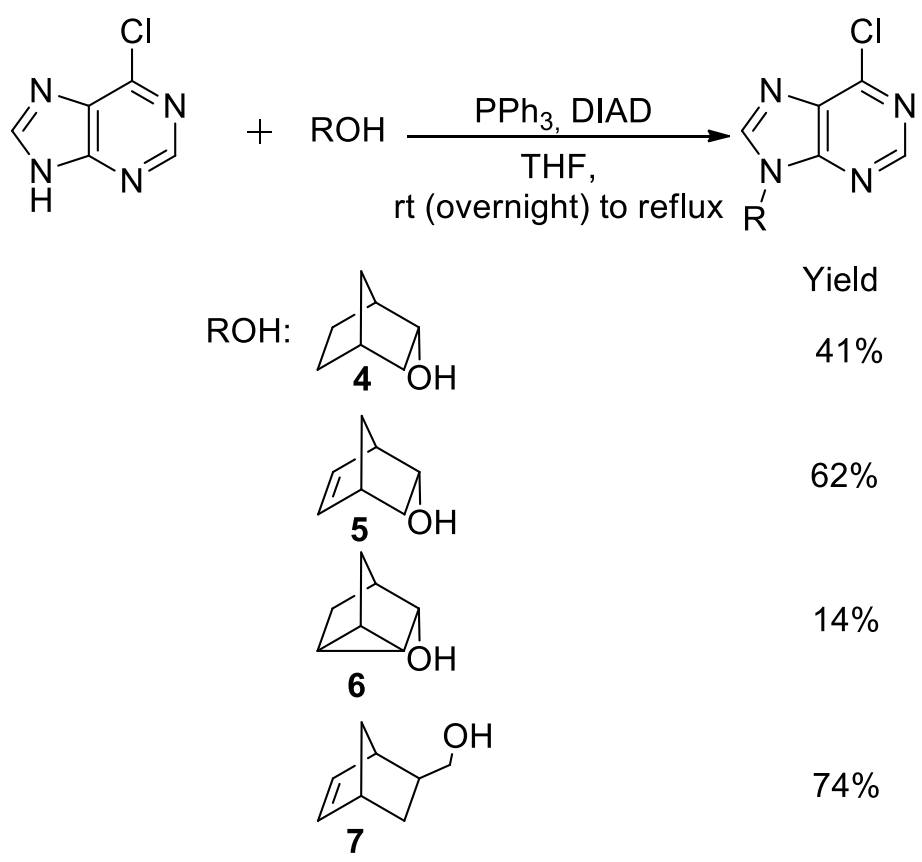

Scheme 3. MR coupling of 6-chloropurine to different bicyclic alcohols as reported by Šála et al. ${ }^{35}$

However, there are alcohols where MR coupling did not succeed, even when several reaction conditions were explored. Few such examples are reported in the literature by Chen et al. ${ }^{36}$ during assembly of fluorinated acyclic nucleoside phosphonates containing cytosine and adenine, by Brémond et al. ${ }^{37}$ and Kasula et al. ${ }^{38}$ in an attempted synthesis of aristeromycin analogs embodying 6-chloropurine and 7-deazapurine moieties, respectively. Rosen et al. ${ }^{39}$ also failed the coupling of cytosine and 2-amino-6-chloropurine to monofluorinated cyclopropane sugar mimetics. The alternative pathway was based on the conversion of the free 
hydroxy group into e.g. mesylate or tosylate, followed by the conventional $\mathrm{S}_{\mathrm{N}} 2$ reaction to couple the nucleobase, in two reaction steps.

The solubility of the nucleobase can also have a noticeable effect on the outcome of the reaction. While a variety of solvents can be used for $\mathrm{MR},{ }^{10}$ the most frequently used for nucleobase coupling is THF. The low solubility of nucleobases such as adenine ${ }^{40}$ and $N^{4}$-benzoyl cytosine ${ }^{41}$ in this solvent have hampered their use in MR. One good example of the importance of nucleobase solubility is given by Bazile et al. ${ }^{42}$ who found out that the yield of MR coupling of 2-fluoroadenine, which has low solubility in THF, was low (only 27\%), while that for the coupling of its Boc-protected derivative was $88 \%$.

\subsection{Regioselectivity, side reactions and product purification}

The reaction conditions affect the regioselectivity during coupling to purines $\left(\mathrm{N}^{9} / \mathrm{N}^{7}\right)$ and to pyrimidines $\left(\mathrm{N}^{1} / \mathrm{O}\right.$ 2); however, this is mainly an issue for pyrimidines, which rarely lead to a single product, while MR with purines leads mostly to $\mathrm{N}^{9}$ ligation; moreover, the $\mathrm{N}^{3}$ position of uracil and thymine pronucleophiles is protected in most cases to prevent the formation of $\mathrm{N}^{3}$ and O-4 linked nucleoside analogs.

The formation of side products is also frequent, resulting in low reaction yields. In carbasugars embodying an $\alpha, \beta$-unsaturated alcohol, e.g. in compound $\mathbf{8}$ (Scheme 4), the $\beta$-addition of the nucleobase, migration of the double bond and displacement of triphenylphosphane oxide can also take place. ${ }^{43-45}$ Scheme 4 illustrates the results obtained by Kumamoto et al. ${ }^{45}$ who was able to prepare nucleoside 10 in only $26 \%$ with the concomitant formation of the analog diastereoisomers $\mathbf{9 a , b}$, obtained in $41 \%$ yield. This effect was mitigated by replacing $-\mathrm{C} \equiv \mathrm{CH}$ by $-\mathrm{CO}_{2} \mathrm{Me}$, resulting in the formation of only the desired product 12 in $58 \%$ yield. ${ }^{45}$
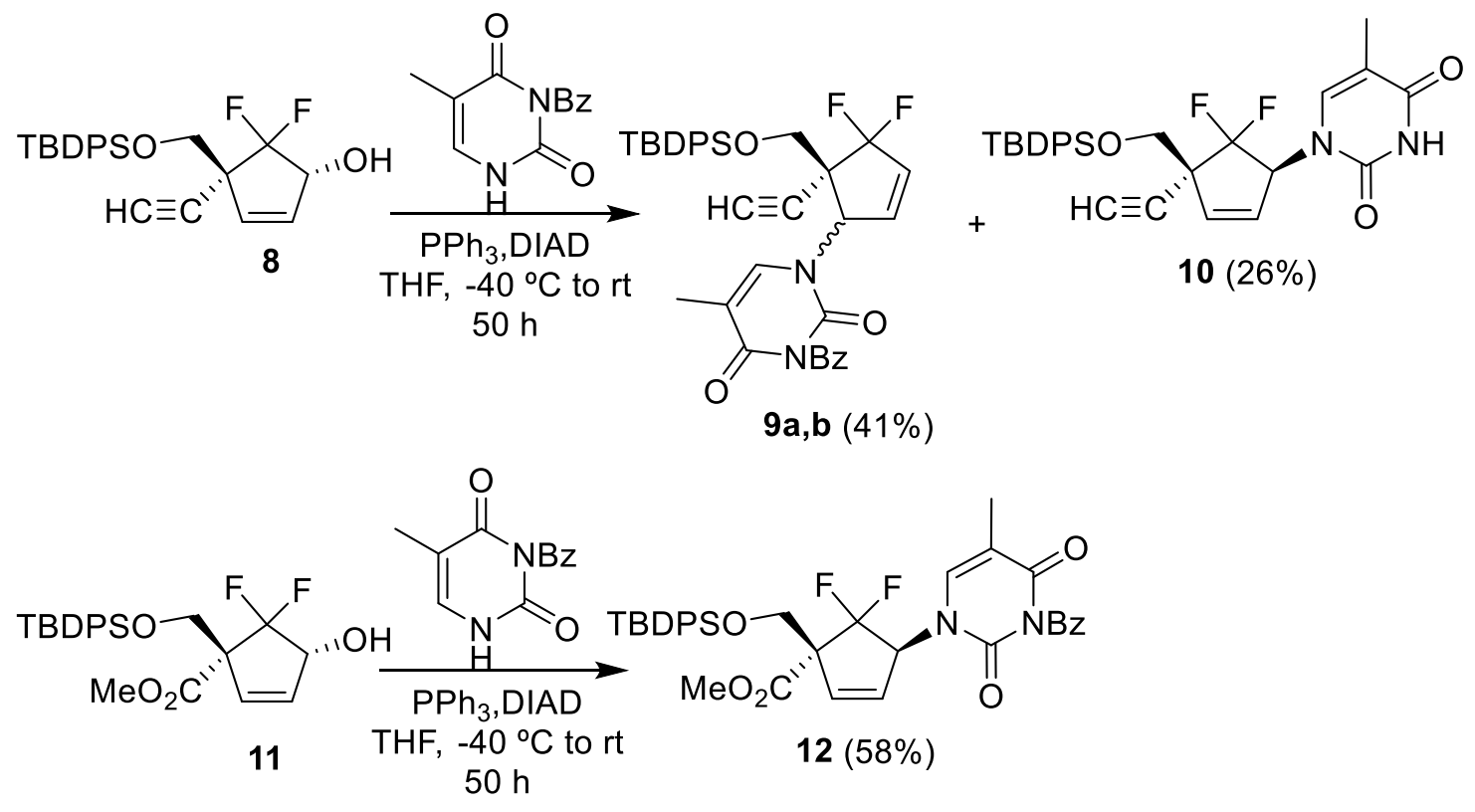

Scheme 4. Nucleophile $\beta$-addition side reaction, as reported by Kumamoto et al. ${ }^{45}$

Another reported side reaction is dehydration of alcohol precursor. Both Viña et al. ${ }^{46}$ and Weising et al. ${ }^{29}$ experienced this problem when attempting to synthesize cis carbocyclic nucleosides (Scheme 5); in the latter case, a relationship between solvent used and the extent of elimination was found, since reactions in MeCN resulted in more elimination than those in THF. Dehydration may also occur in linear alcohols, as shown by 
Guo et $a l . ; 27$ in this case, the elimination reaction occurred when the I-serine amino group was protected by Boc, while the same was not verified with a trityl protecting group.

A

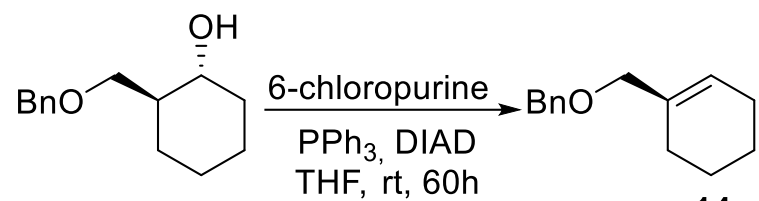

13

THF, rt, $60 \mathrm{~h}$

14

B

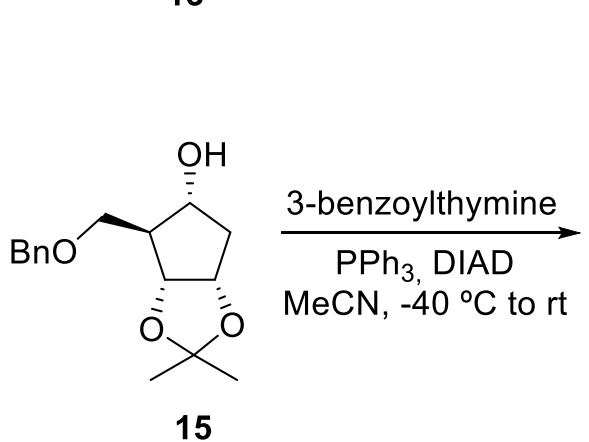

C

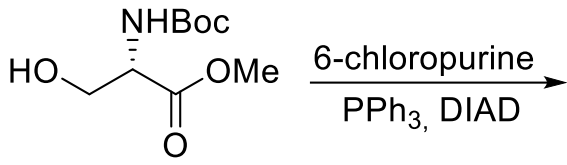

19<smiles></smiles>

16<smiles>Cc1cnc(O[C@@H]2C[C@@H]3OC(C)(C)O[C@H]3[C@@H]2COc2ccccc2)[nH]c1=O</smiles>

17<smiles>CC1(C)O[C@H]2C=C[C@H](COCc3ccccc3)[C@H]2O1</smiles>

18<smiles>C=C(NC(=O)OCc1ccccc1)C(=O)OC</smiles>

20

Scheme 5. Alcohol dehydration, as reported by Viña et $a l .{ }^{46}(\mathrm{~A})$, Weising et $a l .{ }^{29}(\mathrm{~B})$ and Guo et $a l .{ }^{27}(\mathrm{C})$.

Product purification is also a challenge. ${ }^{29,47-52} \mathrm{MR}$ reaction mixture is usually quite complex, containing remaining excess reagents, the dialkyl hydrazine-1,2-dicarboxylate derivative, triphenylphosphane oxide, the desired product and, in some cases, also side products. Therefore, tedious purification processes result in low product yields. ${ }^{50}$ One solution practiced is the use of crude products in the following step, leading to separable products. ${ }^{49,51}$ Also investigation of other appropriate nucleobases may be a strategy towards nucleoside analog purification. ${ }^{48}$

\section{3. $M R$ as an alternative to nucleobase coupling failure}

Common nucleobase coupling strategies are not efficient for all target molecules, and MR can be the appropriate alternative, as shown by Singh et al.. ${ }^{53}$ The attempt to perform a nucleophilic substitution $\left(S_{N} 2\right)$, intended to transform the carbasugar $\mathbf{2 1}$ into the entecavir analog $\mathbf{2 2}$ failed, leading instead to the addition of the nucleobase in the $\beta$ position and migration of the double bond to afford compound 23 (Scheme 6); however, MR starting from 24 gave compound 22 in 65\% yield. 


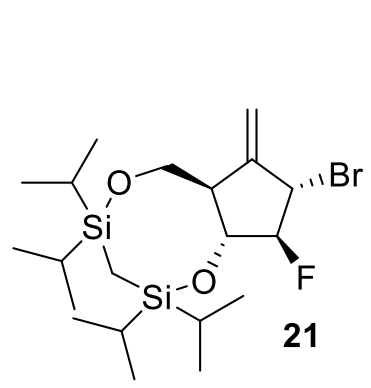<smiles>CC(C)(C)O[R16](=O)(O)c1ncnc2[nH]cnc12</smiles>

$\mathrm{K}_{2} \mathrm{CO}_{3}, 15$-crown-5-ether

DMF, $60^{\circ} \mathrm{C}, 4 \mathrm{~h}$

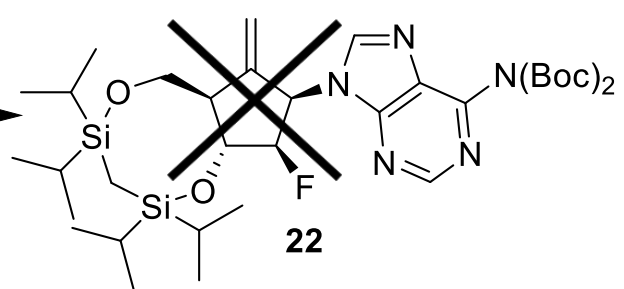

22

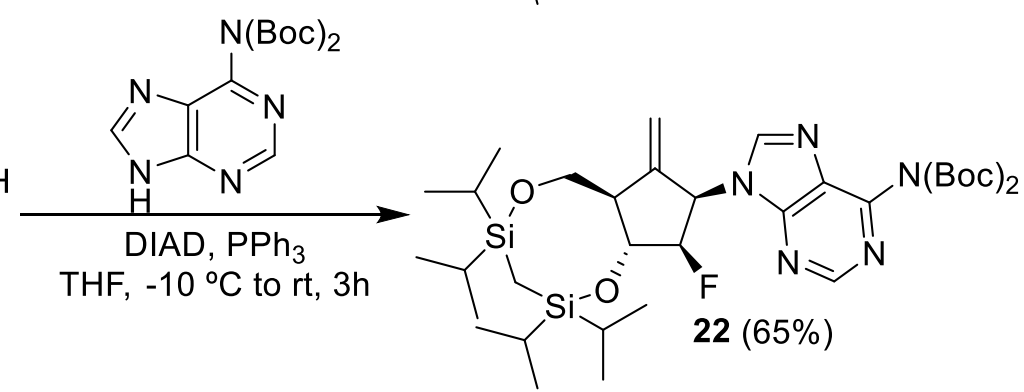

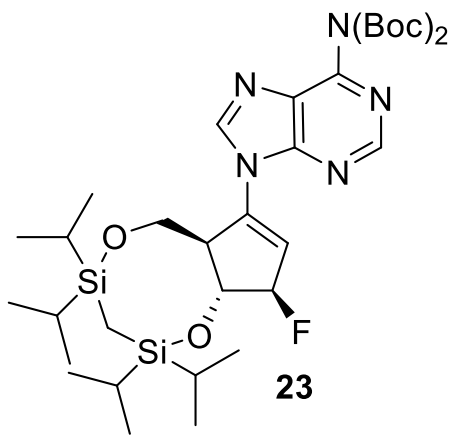

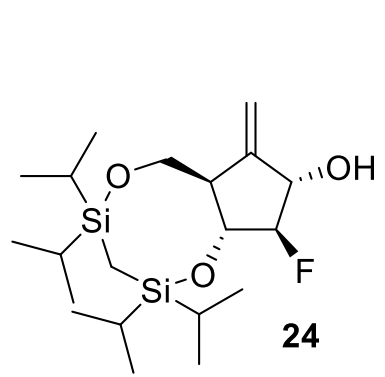

Scheme 6. Nucleobase $\beta$-addition with migration of double bond, a competitive reaction to the proposed $S_{N} 2$ substitution, as reported by Singh et al. ${ }^{53}$

MR was successfully used by Douadi et al., ${ }^{54}$ Christian et al., ${ }^{55}$ and Yang et al. ${ }^{56}$ to afford nucleoside analogs 26, 28 and 30, starting from carbasugar substrates embodying a cyclopent-2-en-1-ol (Scheme 7), while palladium-catalyzed allylic substitution, one of the most common procedures for nucleobase coupling, did not produce the desired carbocyclic nucleoside. MR is also an alternative to nucleophilic substitution of unstable tosylated and mesylated substrates. ${ }^{52}$

A

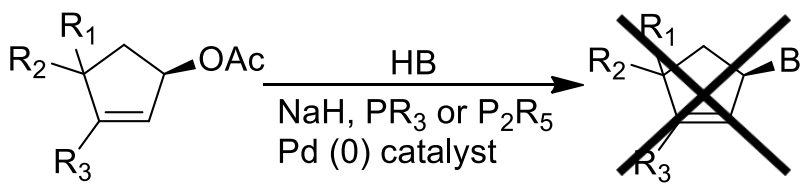

HB 6-chloropurine or 3-benzoyluracil
B<smiles>CC1=C[C@@H](O)C[C@]12COC(C)(C)O2</smiles>

25<smiles>CC1=CC(O)CC1=O</smiles>

27

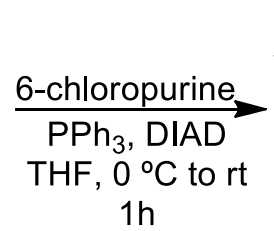

$\underset{\mathrm{PPh}_{3}, \text { DIAD }}{\stackrel{\text { 6-chloropurine }}{\mathrm{THF}, \mathrm{rt}, 12 \mathrm{~h}}}$<smiles>CC1=CC(n2cnc3c(Cl)ncnc32)C[C@]12COC(C)(C)O2</smiles>

26 (79\%)<smiles>CC1=CC(n2cnc3c(Cl)ncnc32)CC1=O</smiles>

$28(54 \%)$

\section{3-benzoyluracil}

C<smiles>O[C@H]1C=C[C@@H]([C@H](Br)COCc2ccccc2)[C@H]1F</smiles>
$\mathrm{PPh}_{3}, \mathrm{DEAD}, \mathrm{THF}$ $0^{\circ} \mathrm{C}$ to rt, overnight 2. $\mathrm{NH}_{3} / \mathrm{MeOH}$ 29<smiles>C[C@H](OCc1ccccc1)[C@H](O)[C@@H]1C=C[C@H](n2ccc(=O)[nH]c2=O)[C@@H]1F</smiles>

30 (40\%, two steps)

Scheme 7. MR coupling to cyclopentene derivates as an alternative to $\mathrm{Pd}(0)$ catalyzed acetyl displacement, as described by Douadi et al. ${ }^{54}$ (A), Christian et al. ${ }^{55}$ (B) and Yang et al. ${ }^{56}$ (C). 
Failure to couple nucleobases to epoxides for the synthesis of isonucleosides type $\mathbf{3 4}$ encouraged Yoshimura et al. to treat the epoxide with thiophenol ${ }^{57}$ or (4-methoxyphenyl)methanethiol ${ }^{58}$ giving compounds type 32, which were then submitted to MR. Stereoselective attack of the nucleobase to the episulfonium intermediate type $\mathbf{3 3}$ gave the nucleoside analog 34 (Scheme 8). Both 6-chloropurine and 3benzoylthymine were successfully coupled by this methodology in good yields $(83 \%-80 \%$ for 6 -chloropurine and $52 \%-59 \%$ for 3-benzoylthymine).

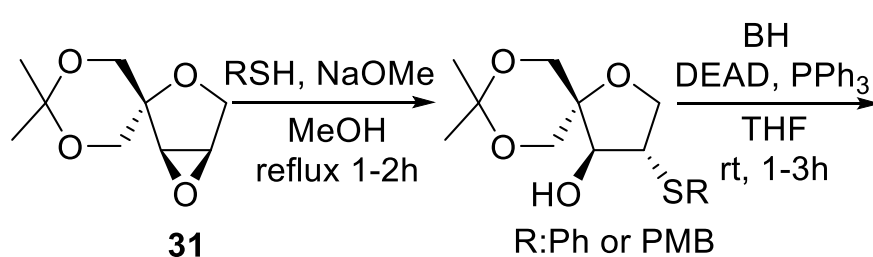

32



33

Scheme 8. Nucleobase coupling by MR via episulfonium intermediate 33, performed by Yoshimura et al. ${ }^{57,58}$

\section{Purine Coupling}

The direct MR coupling of the two canonical purine nucleobases, adenine and guanine, is not, in most cases, the most applied methodology for nucleoside analog synthesis. Although adenine has been used as a pronucleophile, ${ }^{43,59-62}$ the strategy to obtain an adenine nucleoside relies mainly on the coupling of a nucleobase precursor, followed by transformation of the purine to adenine moiety.

No examples of successful coupling of guanine have been reported in the last ten years, as it does not react under the conditions producing moderate yields with other nucleobases, ${ }^{52,31,36}$ which may result from guanine's extremely low solubility, ${ }^{36}$ even under reflux conditions. ${ }^{31}$

\subsection{Adenine and adenine precursors' coupling}

Like guanine, adenine also has a low solubility in THF. ${ }^{40}$ Alternatively, 1,4-dioxane can be used as solvent in MR with this nucleobase, allowing for moderately good coupling yields when reacting with primary alcohols of carbasugar analogs. Illustrative examples were reported by Csuk \& Thiedee, ${ }^{59}$ who obtained the nucleoside analog 36 in $72 \%$ yield when coupling adenine to the difluorocyclopropane derivate 35 , and by Franzyk \& Stermitz. ${ }^{60}$ with the preparation of the carbocyclic nucleoside 38 in $68.5 \%$ yield (Scheme 9). 
A

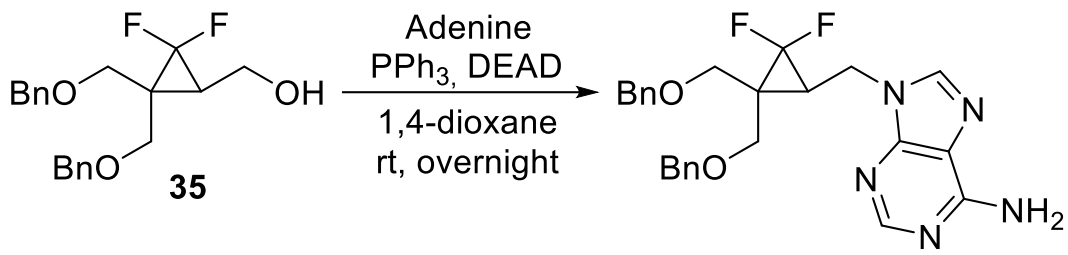

$36(72 \%)$

B



37

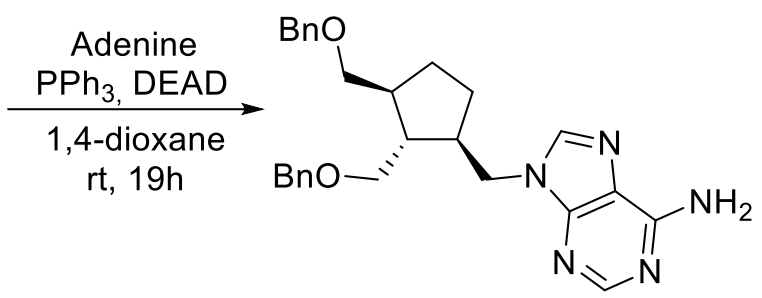

$38(68.5 \%)$

Scheme 9. Successful coupling of adenine as reported by Csuk \& Thiedee ${ }^{59}(A)$, and Franzyk \& Stermitz ${ }^{60}(B)$.

Nevertheless, in most recent reports, alternative pronucleophiles have been used to obtain adenine nucleoside analogs, namely 6-chloropurine and 6-[bis(tert-butoxycarbonyl)amino]purine (Scheme 10).<smiles>Clc1ncnc2[nH]cnc12</smiles>

6-chloropurine

6-[bis(tert-butoxycarbonyl)amino]purine

Scheme 10. Structure of adenine precursors used in MR.

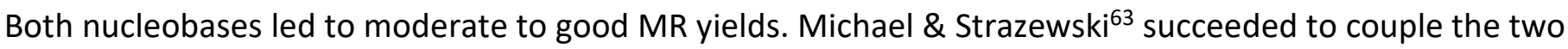
pronucleophiles to carbasugar 39, obtaining compounds $\mathbf{4 0}$ and $\mathbf{4 2}$ in $\mathbf{8 2 \%}$ and $95 \%$ yield, respectively (Scheme 11). However, sugar deprotection of $\mathbf{4 0}$ with TFA gave the unexpected hypoxanthine derivative $\mathbf{4 1}$. Another example of Boc-protected 6-aminopurine coupling was reported by Liu et al, ${ }^{64}$ who coupled this nucleobase derivative to carbasugars $\mathbf{4 3 , 4 4}$ and 45 affording the nucleoside analogs in $77 \%, 87 \%$ and $88 \%$, respectively (Scheme 12). 




Scheme 11. High yield coupling of adenine precursors to a bicyclic carbasugar, and the formation of hypoxanthine derivative $\mathbf{4 1}$, as described by Michael \& Strazewski et al. ${ }^{63}$<smiles>[R]OC(=[18O])c1ncnc2[nH]cnc12</smiles>

$\mathrm{ROH}$ :

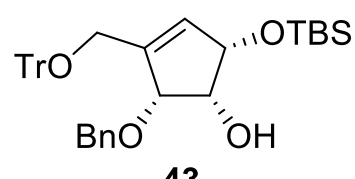<smiles>CC1(C)O[C@H]2C=C(CO[Te])[C@@H](O)[C@H]2O1</smiles><smiles>O[C@H]1C=C(CO[Te])[C@@H](Br)[C@H]1F</smiles><smiles>[R]n1cnc2c(N(C(C)(C)C)C(C)(C)C)ncnc21</smiles>

Yield $77 \%$ $87 \%$ $88 \%$

Scheme 12. High yield coupling of Boc-protected 6-aminopurine to three different secondary alcohols, as reported by Liu et al. ${ }^{64}$

Both nucleobase derivatives, when linked to the sugar moiety, can be converted to give the corresponding adenine nucleosides. Reaction of 6-chloropurine to adenine requires high temperatures in methanolic $\mathrm{NH}_{3}$, commonly in high pressure vessels, ${ }^{40}$ harsher reaction conditions than those for deprotection of 6 -[bis(tertbutoxycarbonyl)amino]purine achieved at room temperature. ${ }^{65}$ Moreover, 6-chloropurine is sensible to acid media, as reported by Michael \& Strazewski, ${ }^{63}$ leading to hypoxanthine derivatives, e.g. compound 41 (Scheme 
11). Nevertheless, 6-chloropurine is quite used for nucleoside analog synthesis as it can be transformed into a variety of nucleobases, and in some cases gives better yields then the Boc-protected 6-aminopurine, as reported by Guo et al. for its coupling with $N$-protected L-serine methyl ester. ${ }^{27}$

\subsection{Guanine precursors' coupling}

Guanine nucleoside analogs are frequently prepared by coupling 2-amino-6-chloropurine and derivatives, namely 2-acetamido-6-chloropurine, ${ }^{44}$ 2-(tert-butoxycarbonyl)amino-6-chloropurine ${ }^{33}$ and 2-[bis(tertbutoxycarbonyl))amino]-6-chloropurine, followed by acid ${ }^{66}$ or basic treatment. ${ }^{67}$

Mohamed et al. ${ }^{65}$ achieved the coupling of 2-amino-6-chloropurine to a carbocyclic vinylphosphonate by MR to give the corresponding nucleoside analog in $80 \%$ yield, which was transformed in the carbocyclic vinylphosphonate derivative of guanine. Also, Miralles-Llumà et al. ${ }^{66}$ took advantage of MR to couple this nucleobase to a cyclobutyl unit obtaining $\mathbf{4 7}$ in $\mathbf{8 7 \%}$ yield. However the same nucleobase failed to couple with the alcohol 48, but with the 2-[bis(tert-butoxycarbonyl)amino]-6-chloropurine, MR coupling generated the nucleoside analog 50 in $60 \%$ yield (Scheme 13). The versatility of 2-amino-6-chloropurine was also shown by Weising et al., ${ }^{67}$ who converted the carbocyclic nucleoside $\mathbf{5 1}$ into abacavir and carbovir (two antiviral drugs) in a single step (Scheme 14).
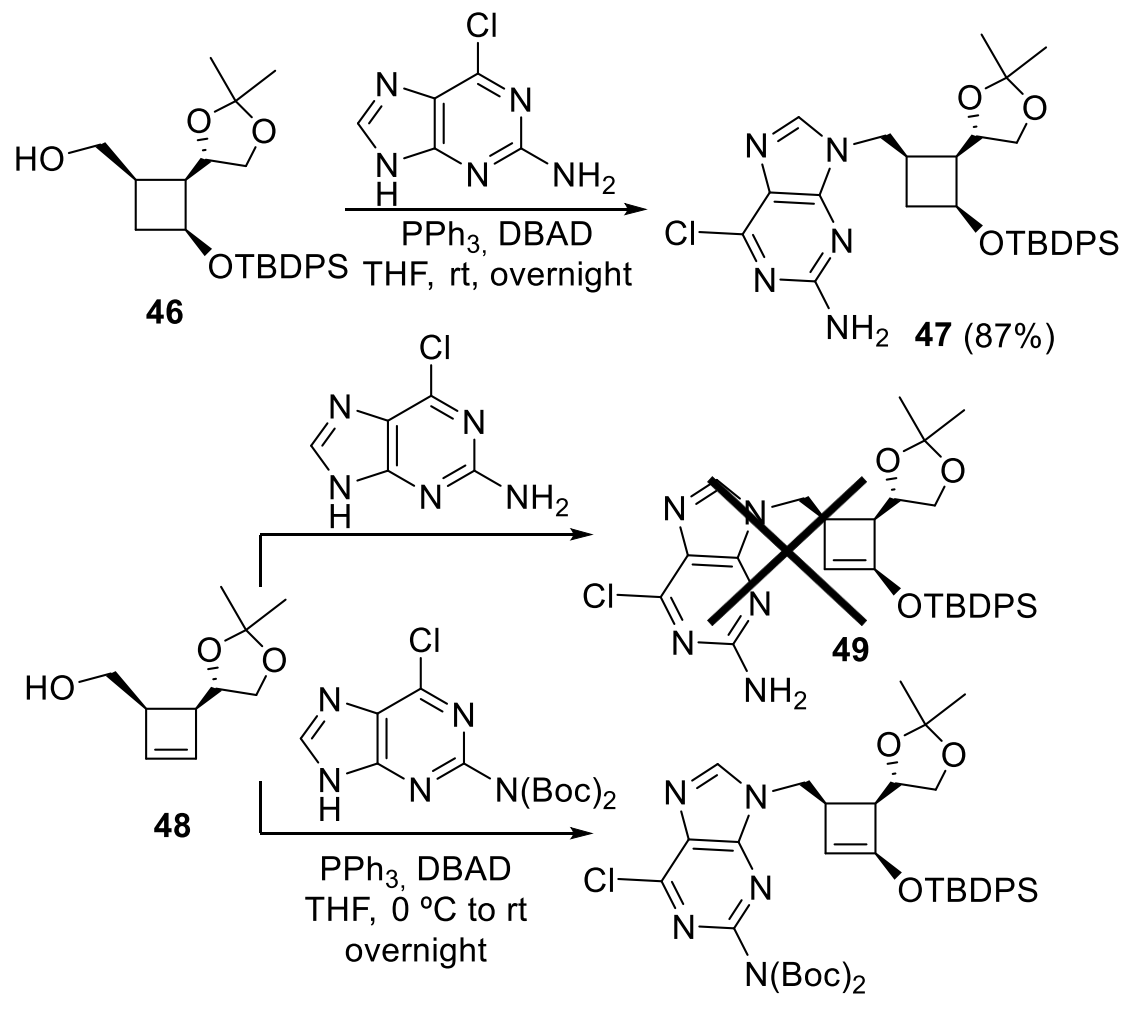

$\mathrm{NH}_{2} \quad 47(87 \%)$

$50(60 \%)$

Scheme 13. Coupling of guanine precursors to two different carbasugars has been reported by Miralles-Llumà et al. ${ }^{66}$ 


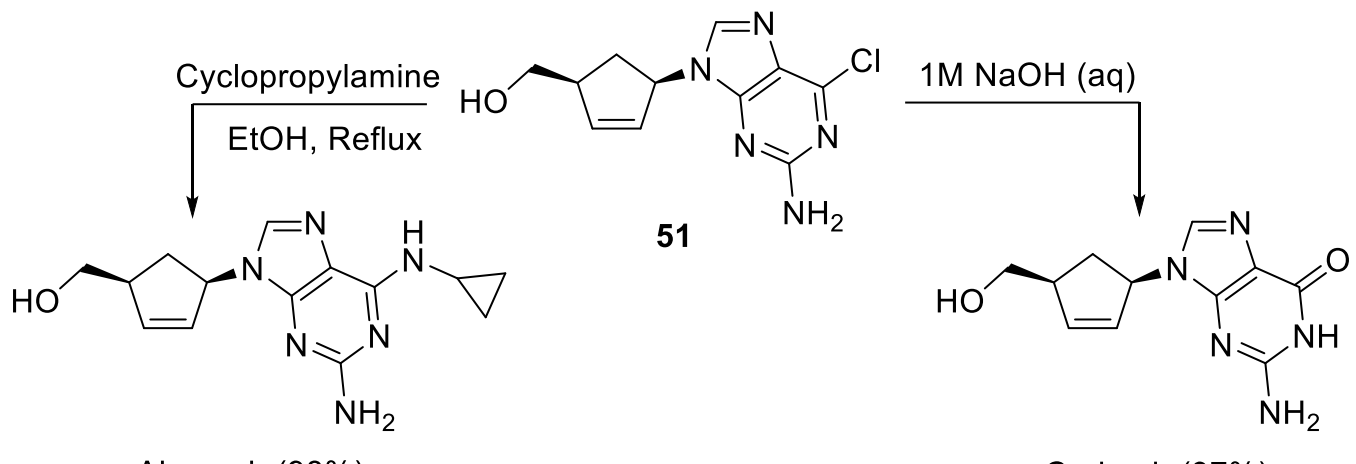

Abacavir (98\%)

Carbovir (97\%)

Scheme 14. High yield, one step conversion of $\mathbf{5 1}$ into the antiviral compounds abacavir and carbovir. ${ }^{67}$

An alternative to chlorinated guanine precursors is a nucleobase embodying a diphenylcarbamate at position 6 with its 2-amino group protected with the 2-methylethylcarbonyl group. This guanine precursor was coupled to the diprotected glycerol 52 by Krishnamurthy et al. ${ }^{68}$ via MR in yields ranging from $47 \%$ to $58 \%$ (Scheme 15). This acyclic nucleoside, derived from glycerol, was prepared for its further exploration in oligonucleotide chemistry aiming to discover new nucleic acid mimetics with base-pairing properties.

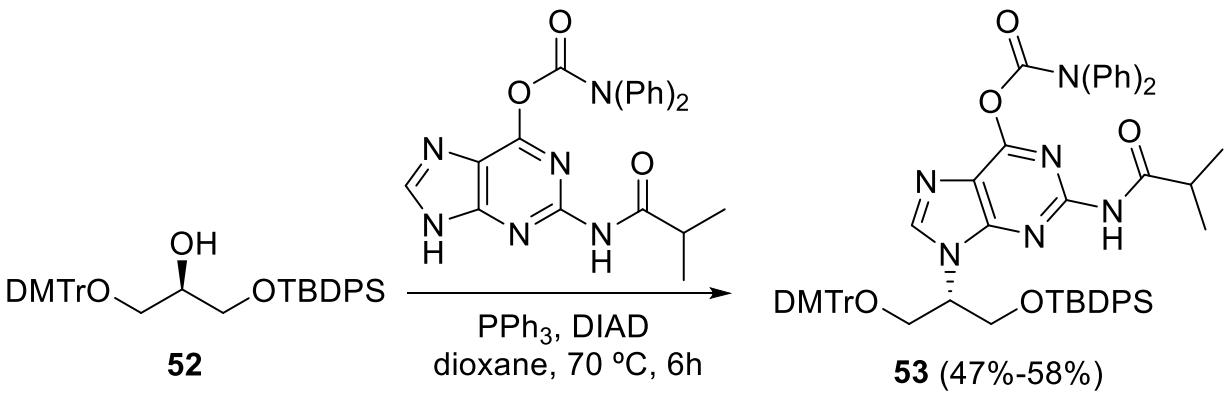

Scheme 15. Synthesis of the acyclic sugar nucleoside analog 53 derived from 1,3-diprotected glycerol 52 via MR. ${ }^{68}$

Hollenstein \& Leumann ${ }^{69}$ succeeded to couple the same nucleobase to the acyclic diol $\mathbf{5 4}$ through a highly regioselective MR, affording the acyclic nucleoside analog 55 in 59\% yield (Scheme 16). This structure served as a precursor to access new DNA mimetics with potential binding affinity to complementary oligonucleotides.

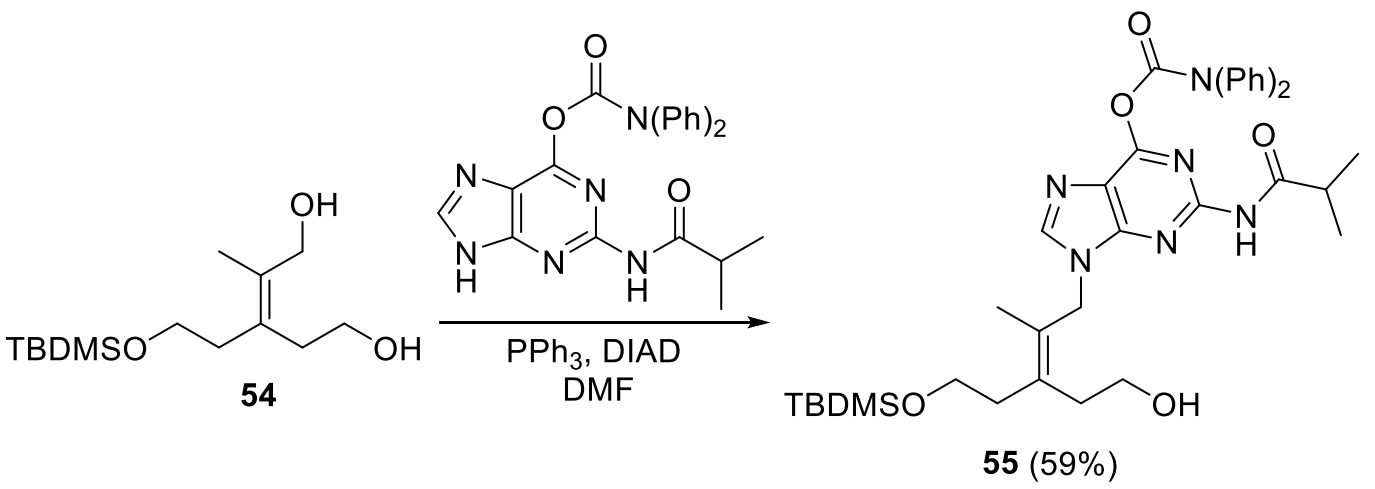

Scheme 16. Synthesis of acyclic nucleoside 55 as reported by Hollenstein \& Leumann. ${ }^{69}$ 
A similar purine was proposed by Lu et al., ${ }^{31}$ with an acetamido group at position 2, which has a good solubility in THF and high reactivity. The authors succeeded to couple this protected nucleobase with primary, secondary and aromatic alcohols by MR in yields ranging from $70 \%$ to $80 \% .{ }^{31}$ This base was also linked through MR to alkyl chains by Wamberg et al., ${ }^{34}$ aiming to generate new molecules for noncovalent anchoring to amphiphilic membranes. While these two examples do not describe nucleoside analog synthesis, they illustrate $\mathrm{N}^{9}$-guanine alkylation through $\mathrm{MR}$ and may therefore be potentially useful for the synthesis of isonucleoside, carbocyclic nucleosides and acyclic nucleosides.

\subsection{Regioselectivity and alkylation of purine amino groups}

Purine coupling to carbohydrates and carbasugars through MR is regioselective for the $\mathrm{N}^{9}$ position of the nucleobase, with only some rare examples of formation of $\mathrm{N}^{7}$-linked carbocyclic nucleosides as minor products, ${ }^{70-72}$ and one report of $\mathrm{N}^{3}$ coupling as a major product in isonucleoside synthesis, with both adenine and 8-azaadenine as pronucleophiles. ${ }^{73}$

$\mathrm{MR}$ regioselectivity conducting to the $\mathrm{N}^{9}$ linkage has also been found in acyclic nucleosides. An example is the reaction of bis[(terc-butylcarbonyloxy)methyl] 4-hydroxy-but-2-enylphosphonate with 6-chloropurine or 2amino-6-chloropurine, affording, under MR conditions, the $\mathrm{N}^{9}$ acyclic nucleosides in $74 \%$ and $50 \%$ yield, respectively, ${ }^{74}$ while a $21 \% \mathrm{~N}^{9}: \mathrm{N}^{7}(7: 3)$ reaction mixture was obtained when the corresponding 4-bromo derivative reacted with the base by a $S_{N} 2$ reaction. ${ }^{74}$ However, some reports show that, even under MR conditions, the regioselectivity for the $\mathrm{N}^{9}$ isomer can be rather low, reaching proportions of $N^{9} / N^{7}(5.6: 1)$, as shown by Manvar \& Shah ${ }^{26}$ for the coupling of 2-amino-6-chloropurine to the terminal hydroxy group linked to the ethoxymethylphosphonate chain. $\mathrm{N}^{9}$ regioselectivity was also described by Lu et al. ${ }^{31}$ in the synthesis of non-sugar carbon nucleosides through $\mathrm{MR}$, although $\mathrm{N}^{7}$-alkylation also occurred when 2,6-dichloropurine was coupled to some of the alcohols, in $5-18 \%$ yields. Solvent, reaction temperature, azodicarboxylate reagent (DEAD or DIAD), and amount of non-limiting reagents also influence regioselectivity. Both Lu et al. ${ }^{31}$ and Manvar \& Shah ${ }^{26}$ described that, by adding alcohol (1.05 equiv.), DIAD (1.05 equiv.) and PPh $_{3}$ (1.05 equiv.) twice, and running the reaction for 6 hours after each addition, almost exclusively $\mathrm{N}^{9}$ alkylation occurred, while adding the same reagents' amount but in one single portion gave lower regioselectivity [22.3:1 $\left.\left(N^{9}: N^{7}\right)\right]$ and lower yields. ${ }^{26,31}$

While most examples of purine alkylation through MR happen in the nucleobase $\mathrm{N}^{9}$ and $\mathrm{N}^{7}$ positions, the latter as minor reaction products, there is also the possibility of using MR to alkylate other positions of the purine. MR is highly chemoselective conducting to reaction at the $\mathrm{N}^{9}$ position, even with bases bearing a free amino group, namely 2-aminochloropurines. However, alkylation of the 2-amino group of $\mathrm{N}^{9}$-protected nucleobases was carried out by MR when using an excess of primary and secondary alcohols to give compounds type 57, in high yields (86-93\%). ${ }^{75}$ Alkylation of the (tert-butoxycarbonyl)amino group in position 6 of the adenine derivative $\mathbf{5 8}$ by MR, with both primary and secondary alcohols, also gave nucleoside analogs in high yields (81-91\%), deprotected by acid treatment (Scheme 17). ${ }^{76}$ Noteworthy, these MRs only succeeded because the amino group is Boc-protected, which increases the acidity of this non-aromatic NH group. 


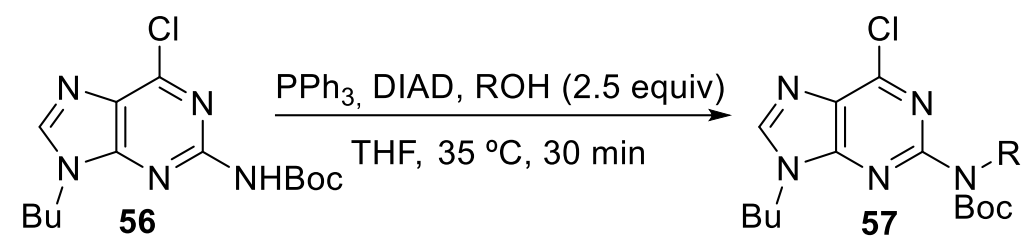<smiles>[R]Nc1ncnc2[nH]cnc12</smiles>

Scheme 17. Alkylation of the 2-amino group and the 6-amino group, of guanine and adenine analogs, respectively, as presented by Fletcher et al. ${ }^{75,76}$

\section{Pyrimidine Coupling}

The coupling of pyrimidines by MR is mostly restricted to 3-benzoyluracil and 3-benzoylthymine, which behave similarly as pronucleophiles. Cytosine is not commonly used, although some derivatives, in which the amino group is protected with a benzoyl group, ${ }^{77}$ an acetyl group ${ }^{27}$ or diprotected with bis(tert-butoxycarbonyl) ${ }^{78}$ have been coupled with moderate to good yields.

\section{1. $\mathrm{N}^{1} / 0-2$ Regioselectivity}

MR regioselectivity is the main issue when the pronucleophile is a pyrimidine. Pyrimidines may undergo tautomerization in solution, as shown in Scheme 18. Since both $\mathrm{NH}$ and $\mathrm{OH}$ groups can act as pronucleophiles in $\mathrm{MR}$, the use of this reaction with pyrimidines will usually result in mixtures of $\mathrm{N}$-alkylated and $\mathrm{O}$-alkylated products. Moreover, it is necessary to protect the $\mathrm{N}^{3}$ position, usually with a benzoyl group, to avoid linkage to $\mathrm{N}^{3}$ and $0-4$, which can result in the formation of nucleoside analogs embodying two sugar moieties. ${ }^{79,80}$

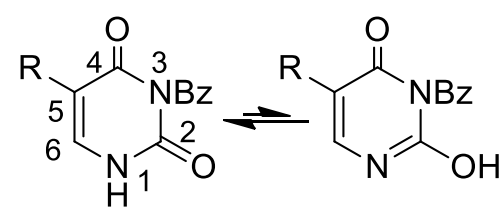

Scheme 18. Tautomerization of uracil and thymine derivatives.

The regioselectivity of the reaction depends on multiple factors. Leung et $a{ }^{.81}$ carried out the optimization of the MR experimental procedure for the coupling of $\mathrm{N}^{3}$-benzoylthymine to cyclopentanol 60 (Scheme 19, Table 1) by testing different solvents, reagent proportions and reaction temperature $\left(0^{\circ} \mathrm{C}\right.$ and $\left.\mathrm{rt}\right)$. The results showed that the highest regioselectivity and the highest yield for $\mathrm{N}^{1}$-alkylation occurred by using DMF as solvent, in comparison with THF and dichloromethane (solvent as the only variable). It was also shown that, by increasing the proportion of the nucleobase relatively to the reagents $\mathrm{Ph}_{3} \mathrm{P}$ and $\mathrm{DIAD}$, at room temperature, the $\mathrm{N}^{1}$-alkylated product yield increased from $53 \%$ to $64 \%$, although at the cost of producing more of O-2 linked product, which yield increased from $8 \%$ to $25 \% .{ }^{81}$ 


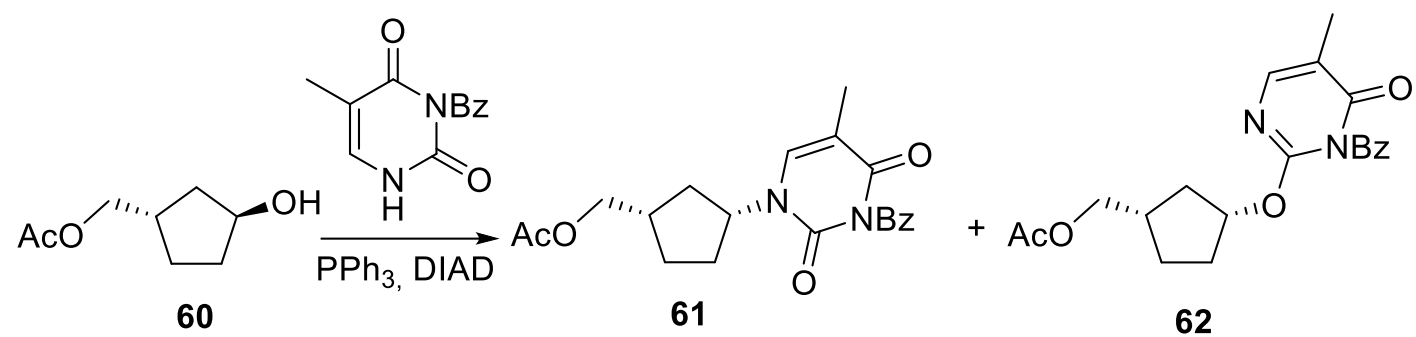

Scheme 19. 3-Benzoylthymine coupling performed by Leung et al. ${ }^{81}$

Table 1. Reaction optimization performed by Leung et $a^{81}$

\begin{tabular}{cccccc}
\hline $\begin{array}{c}\mathrm{PPh}_{3} / \mathrm{DIAD} \\
\text { (equiv.) }\end{array}$ & $\begin{array}{c}\text { 3-Benzoylthymine } \\
\text { (equiv.) }\end{array}$ & Solvent & $\mathrm{T} \mathrm{(o} \mathrm{C})$ & $\begin{array}{c}\mathbf{6 1} \\
\text { Yield } \\
\text { (\%) }\end{array}$ & $\begin{array}{c}\mathbf{6 2} \\
\text { Yield } \\
\text { (\%) }\end{array}$ \\
\hline 2.5 & 1.5 & $\mathrm{CH}_{2} \mathrm{Cl}_{2}$ & $\mathrm{rt}$ & 49 & 35 \\
2.5 & 1.5 & $\mathrm{THF}$ & $\mathrm{rt}$ & 47 & 22 \\
2.5 & 1.5 & $\mathrm{DMF}$ & $\mathrm{rt}$ & 53 & 8 \\
2.5 & 1.5 & $\mathrm{DMF}$ & 0 & 33 & 12 \\
1.5 & 3 & $\mathrm{DMF}$ & 0 & 48 & 20 \\
1.5 & 3 & $\mathrm{DMF}$ & $\mathrm{rt}$ & 64 & 25 \\
\hline
\end{tabular}

Weising et al. ${ }^{29}$ tested MeCN and THF for the coupling of a carbocyclic ribo-nucleoside with analog $\mathrm{N}^{3}$ benzoylthymine, to control regioselectivity and avoid elimination. The results obtained show that in $\mathrm{MeCN}$ a product ratio of 1:1 ( $\left.\mathrm{N}^{1}: 0-2\right)$ was obtained, while in THF the ratio was $1: 4\left(\mathrm{~N}^{1}: 0-2\right)$, favoring $0-2$ ligation. This conclusion should be envisioned as specific for this reaction, as there are examples of regioselective $\mathrm{N}^{1}$ coupling by MR with THF. ${ }^{78}$

While in many cases the yield of MR with pyrimidines is quite good, ${ }^{23,59,75-77}$ there are no reported cases of nearly quantitative yields of $\mathrm{N}^{1}$-linked products, most probably due to the formation of 0 - 2 derivatives.

\section{Coupling of Other Nitrogen Heterocycles}

MR can be employed to synthesize carbocyclic nucleosides comprising $N$-heterocyclic bases with a structure not derived from canonical nucleobases, namely deazapurines. These compounds, including 1-deazapurines, ${ }^{85}$ 3-deazapurines ${ }^{49,51,86-88}$ and 7-deazapurines ${ }^{44}$ have been successfully coupled to alcohols by MR.

Unlike regular purines, the coupling of 3-deazapurine may not be regioselective. Yang et al. ${ }^{87}$ reported an example were alcohol precursors with unsaturated bonds (compounds 63, 64 and 65, Scheme 20) led to $\mathrm{N}^{9}$ and $\mathrm{N}^{7}$ linked isomers, when 3-deaza-6-chloropurine was used as a pronucleophile. However, this regioselectivity may change when the base embodies bulky substituents that produce stereochemical hindrance to the attack of a particular position, as shown by Jha et al. ${ }^{49}$ for the $\mathrm{N}^{7}$ position (Scheme 21). The authors obtained the $\mathrm{N}^{9}$ carbocyclic nucleoside by reaction of the carbasugar 66 with very minor formation of the $\mathrm{N}^{7}$ isomer $(<5-7 \%)$. 


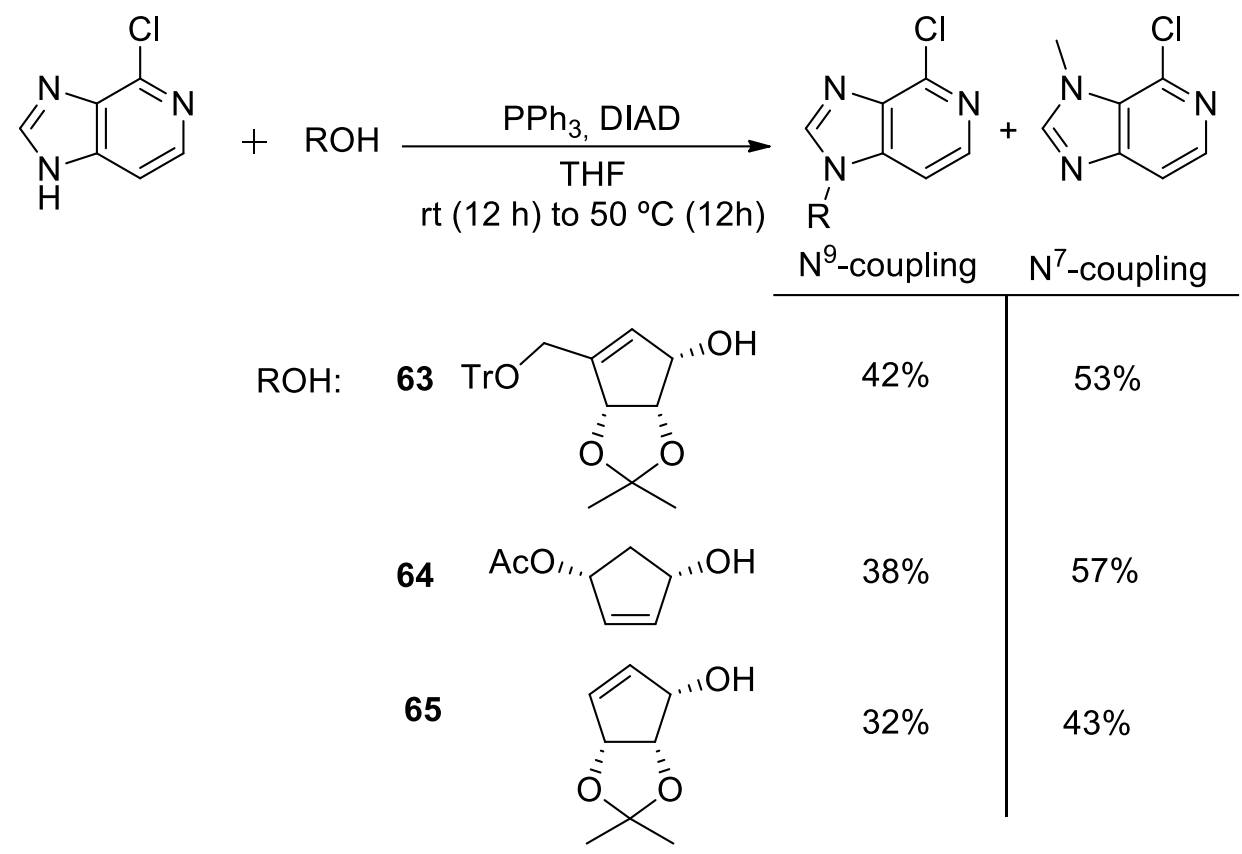

Scheme 20. Non-regioselective coupling of 6-chloro-3-deazapurine to alcohols, as reported by Yang et al. ${ }^{87}$

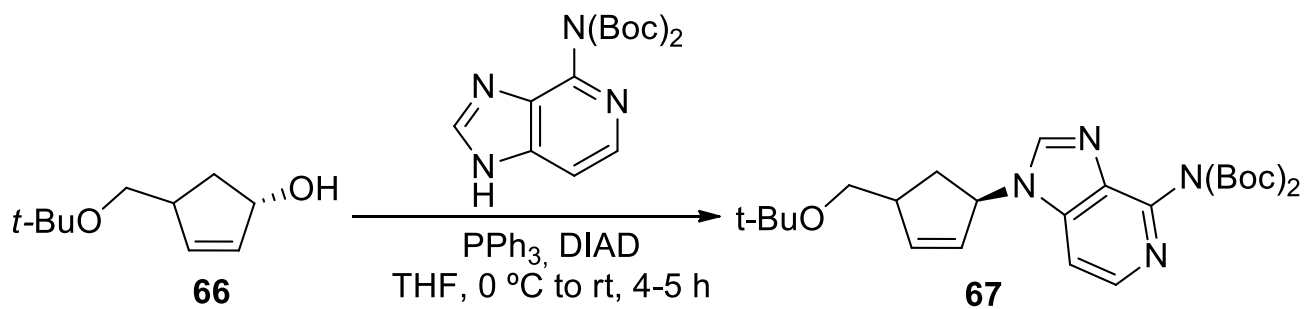

Scheme 21. $\mathrm{N}^{9}$ Regioselective coupling of a 3-deazapurine to the carbasugar 66 resulting from stereochemical hindrance.

6-Azauracil (68) is a pyrimidine analog that can be coupled by MR with high $\mathrm{N}^{1}$ regioselectivity, even without benzoylation of $\mathrm{N}^{3}$, unlike pyrimidines. The enhanced acidity of $\mathrm{N}^{1}$ resulting from the adjacent $\mathrm{N}^{6}$ favored the synthesis of the desired carbocyclic nucleoside $\mathbf{7 0}$. Sugar deprotection afforded $\mathbf{7 1}$ in $54 \%$ yield over the two steps (Scheme 22). ${ }^{89}$<smiles>O=c1cn[nH]c(=O)[nH]1</smiles>

68<smiles>COC[C@H]1C[C@H](O)[C@H]2OC(C)(C)O[C@H]12</smiles>

69<smiles>CC(C)[C@H](COC(C)(C)C)[C@H]1OC(C)(C)O[C@@H]1I</smiles>

70

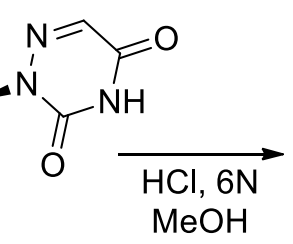
$\mathrm{MeOH}$<smiles>O=c1cnn([C@@H]2C[C@H](CO)[C@@H](O)[C@H]2O)c(=O)[nH]1</smiles>

71 (54\%, two steps)

Scheme 22. Regioselective coupling of unprotected 6-azauracil as reported by Jin et al. ${ }^{89}$

Pursuing the development of novel and selective inhibitors of phosphoribosyltransferase, an enzyme that is crucial for the survival of the parasite Plasmodium falciparum, Klejch et al. ${ }^{28}$ attached a diversity of acyclic 
phosphonates with a free hydroxy group to the antiviral drug favipiravir and to a 4-chlorinated allopurinol precursor via MR (Scheme 23). Experimental conditions were extensively investigated, e.g., reagents proportion, time, temperature, solvent, but the coupling of favipiravir occurred mainly in the 0-2 position (49$90 \%$ isolated yields for different alcohol substrates), or exclusively in this position (Scheme 23), while the coupling of the chlorinated allopurinol precursor produced only the desired $\mathrm{N}^{9}$ regioisomer. ${ }^{28}$

In the search for furanose and pyranose isonucleosides as potential cholinesterase inhibitors for Alzheimer's disease treatment, the purine theobromine (compound 77) has also been coupled to different carbohydrate moieties by MR, with regioselective alkylation of $\mathrm{N}^{1}$ (Scheme 24$){ }^{79,80,90}$

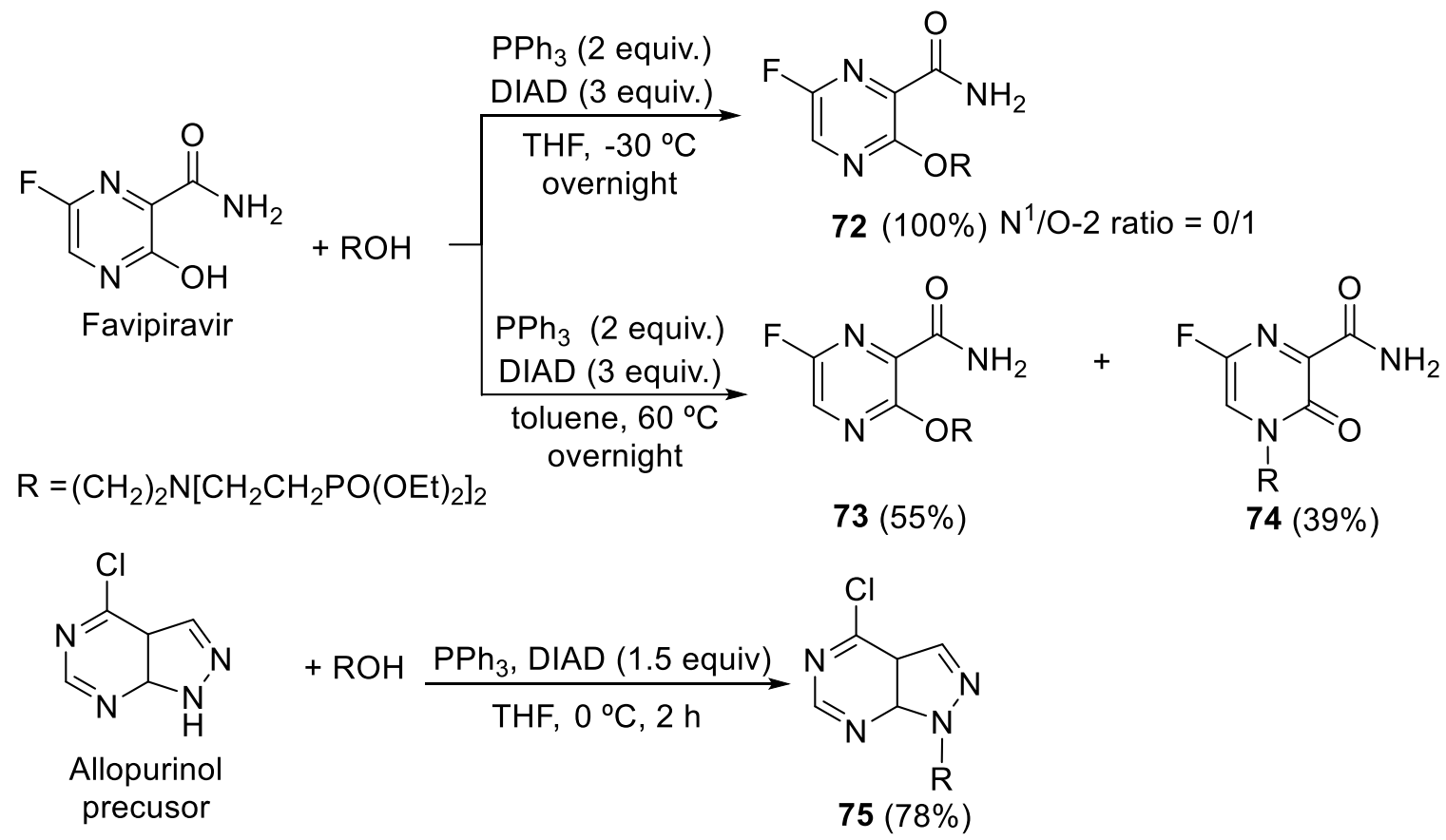

Scheme 23. MR regioselectivity resulting from reaction of favipiravir and 4-chlorinated allpurinol with the $\mathrm{OH}$ group of acyclic phosphonates.

\section{Microwave-assisted MR Coupling}

Microwave-assisted MR (MW-MR) is often an alternative to shorten reaction time and improve reaction yield. One example relies on MR of theobromine $\mathbf{7 7}$ with the primary alcohol 76. Under conventional conditions, the reaction was carried out for $48 \mathrm{~h}$ and gave a very low yield (16\%) of the $\mathrm{N}^{1}$-linked isonucleoside 78 . However, the yield increased to $44 \%$ after 30 min under microwave irradiation (Scheme 24). With the same strategy, it was also possible to couple adenine to carbohydrate 76 in $33 \%$ yield, while under conventional conditions no reaction occurred. ${ }^{80}$ 


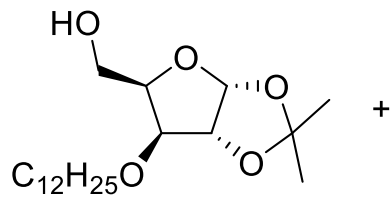

76<smiles>Cn1cnc2c1c(=O)[nH]c(=O)n2C</smiles>

77
$\mathrm{PPh}_{3}, \mathrm{DEAD}, \mathrm{THF}$, $48 \mathrm{~h}, 16 \%$

or $\mathrm{PPh}_{3}, \mathrm{DEAD}$, THF/DMF, $150 \mathrm{~W}$, $65^{\circ} \mathrm{C}, 30 \mathrm{~min}, 44 \%$

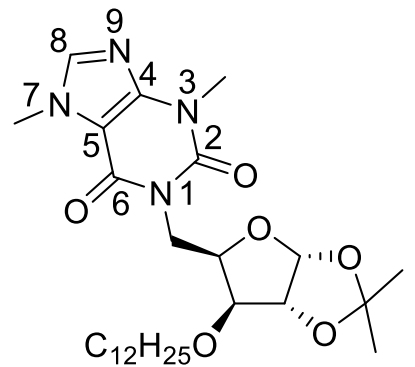

78

Scheme 24. Theobromine coupling by MR under conventional heating and microwave irradiation. ${ }^{80}$

Carbocyclic nucleosides 80-83, analogs of neplanocin, a natural product with potent antitumor and antiviral activities, were synthesized by Liao et al. ${ }^{44}$ The MR yield for base coupling of these 7-deazapurines increased from $20-30 \%$ under conventional heating conditions for sixteen hours, to $40-50 \%$ after 1 minute under microwave irradiation (Scheme 25).

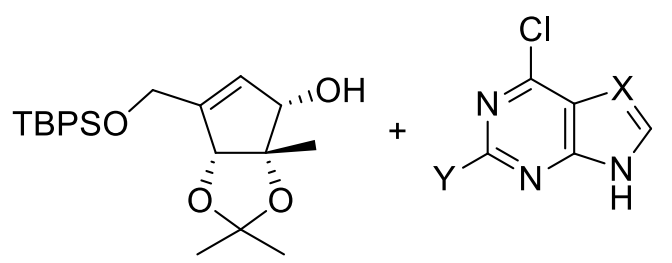

79



$80^{\circ} \mathrm{C}, 1 \mathrm{~min}, 40 \%-50 \%$

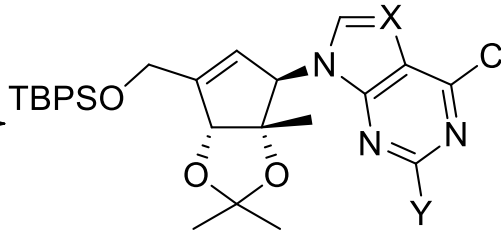

$80 X=\mathrm{CH}, Y=\mathrm{H}$

$81 X=C F, Y=H$

$82 \mathrm{X}=\mathrm{CH}, \mathrm{Y}=\mathrm{NHAC}$

$83 X=\mathrm{CH}, \mathrm{Y}=\mathrm{NH}_{2}$

Scheme 25. Carbocyclic neplanocin analogs by MR under conventional conditions and by MW assisted MR. ${ }^{44}$

Weising et al. ${ }^{29}$ tested MR with THF and MeCN for pyrimidine coupling to the carbasugar 15, in both conventional conditions and under microwave irradiation $\left(100 \mathrm{~W}, 45^{\circ} \mathrm{C}\right)$ (Scheme 26). Interestingly the yield of 84 was not significantly increased (from $18 \%$ to $20 \%$, in MeCN), and the ratio $\mathrm{N}^{1}: 0-2$ was $1: 1$ in both reaction conditions. The same trend was shown for $\mathrm{N}^{3}$-benzoyluracil under $\mathrm{MW}$ assisted $\mathrm{MR} .{ }^{29}$ However, the use of the MW-MR made the purification of the products easier because a smaller excess of reagents was required. Under the same reaction conditions, the coupling of 15 to N-4 acetylcytosine by MW-MR afforded exclusively the 0-2 linked nucleoside analog 86 in $70 \%$ yield. MW-MR was also used to couple 6-chloropurine and 2-amino-6-chloropurine, and the $\mathrm{N}^{9}$-nucleoside analogs were obtained in $80 \%$ and $70 \%$ yield, respectively, when reaction was carried out in THF, as MeCN led to a lower yield (49\%) for 6-chloropurine coupling with $15 .{ }^{29}$ Similar microwave-assisted conditions $\left(100 \mathrm{~W}, 50{ }^{\circ} \mathrm{C}\right)$ were reported for the coupling of 2-amino-6chloropurine to alcohol 87 in $59 \%$ yield after one hour. ${ }^{67}$

These illustrative examples demonstrate that MW-MR may be a step forward for nucleobase coupling by giving considerably shorter reaction times, facilitating nucleoside analog purification, and in some instances also improving reaction yields. 




Nucleobase: O
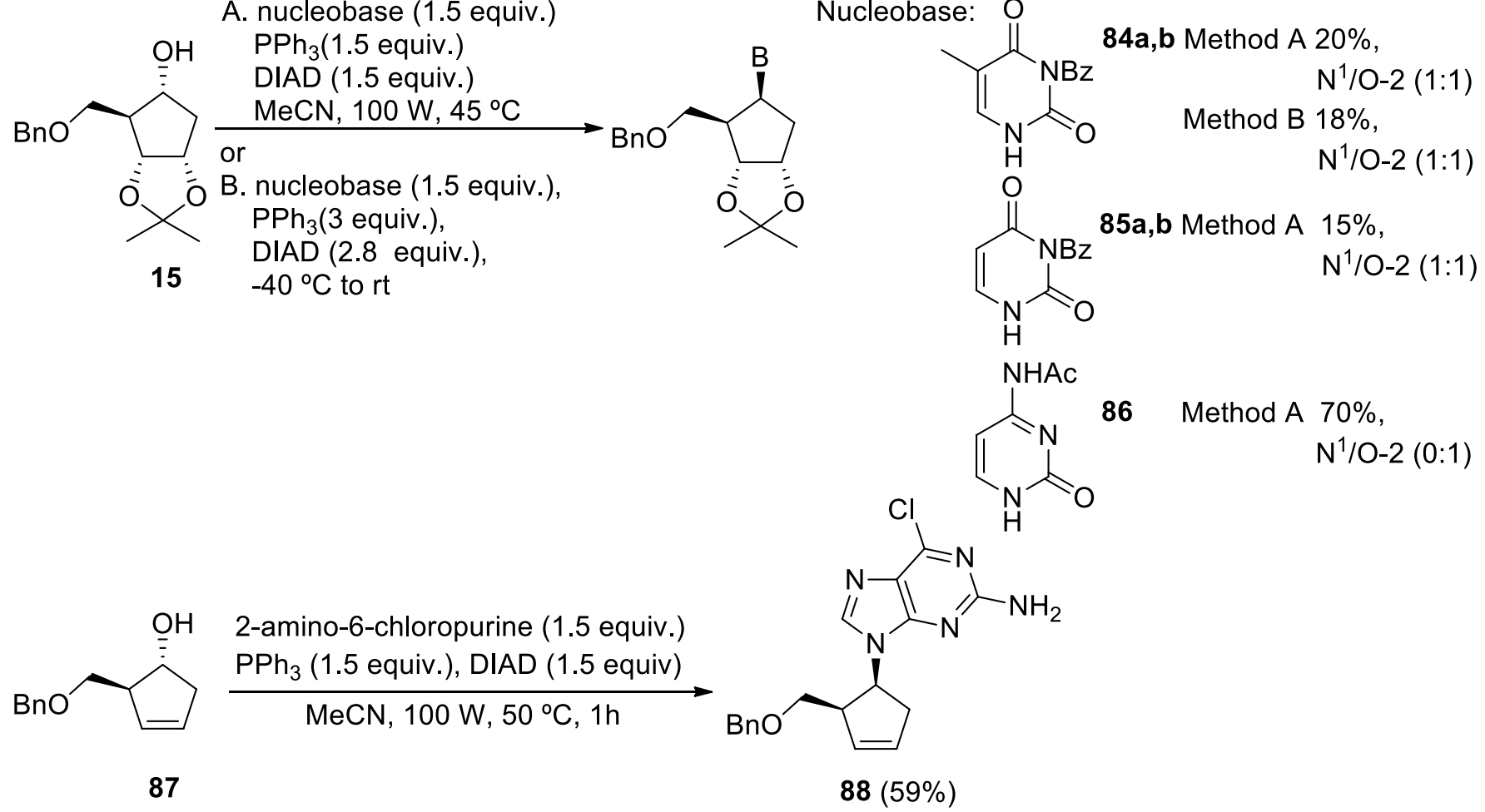

Scheme 26. Microwave-assisted Mitsunobu reactions as reported by Weising et al. ${ }^{29,67}$

\section{Conclusions}

Throughout this survey, multiple aspects affecting the synthesis of nucleoside analogs by MR were highlighted and discussed. Indeed, no single factor, by itself, can determine the success of the reaction, but some conclusions can be withdrawn. First, some alcohol precursors are not suitable for nucleobase coupling, due to their low reactivity, as the tertiary or highly hindered secondary alcohols, some of them suffering side reactions, e.g. elimination or $\beta$ addition on $\alpha, \beta$-unsaturated alcohols. Nucleobases with low solubility have a dramatic effect on yield, and reaction optimization is usually successful if a suitable solvent is found, or if the nucleobase is chemically modified. Some of the reaction parameters that can affect yields, such as temperature or order of addition of reagents, cannot be so easily rationalized, as they change depending on the substrate, pronucleophile, solvent and reagents. Thus, the data available in the literature do not allow any prediction or general recommendation to improve yields. This is particularly noteworthy when it comes to MR with the pyrimidines 3-benzoyluracil and 3-benzoylthymine. Even though both solvent and temperature affect the formation of the undesired 0-2 coupled products, no exact conditions have been reported favoring $\mathrm{N}^{1}$ alkylation; and base coupling conditions must be optimized case by case, aiming at a higher yield of the product resulting from $\mathrm{N}$-ligation. Purine coupling is less problematic, due to $\mathrm{MR} \mathrm{N}^{9}$ regioselectivity. $\mathrm{N}^{7}$ Ligation generates only minor products, and MR coupling with purines leads quite often to high yields of the $\mathrm{N}^{9}$ regioisomers, when appropriate alcohol precursors are used. MR was also applied to alkylate amino group substituents in adenine and guanine precursors, when nucleobase reactive functionality is protected.

Microwave-assisted MR is considerably faster than conventional ones, and in some cases lead to higher product yields, encouraging further developments in nucleoside analog synthesis with this green chemical approach. 
MR has also been used for the coupling of unnatural nucleobases, such has deaza analogs of purines, 6azauracil, as well as other aromatic nitrogen heterocycles, broadening the scope of its application.

It is not our aim to present a comprehensive review on nucleoside base coupling by MR, but instead to highlight the benefits and the drawbacks found in the synthesis of nucleoside analogs, when the classical reactions for the nucleobase coupling do not succeed or give lower yields and regioselectivity. Nonetheless, by considering the numerous examples of the successful application of MR in the synthesis of carbocyclic nucleosides, acyclic nucleosides and isonucleosides, it can be concluded that MR is a viable experimental tool for the coupling of nucleobases to alcohols, opening the door to novel nucleoside analogs.

\section{Acknowledgements}

The authors are grateful to Fundação para a Ciência e a Tecnologia (FCT, Portugal) for the financial support to Centro de Química Estrutural (project UIDB/00100/2020).

\section{References}

1. Jordheim, L. P.; Durantel, D., Zoulim, F.; Dumontet, C. Nat. Rev. Drug Discov. 2013, 12, 447-464. https://doi.org/10.1038/nrd4010

2. Tsesmetzis, N.; Paulin, C. B. J.; Rudd, S. G.; Herold, N. Cancers 2018, 10, 240. https://doi.org/10.3390/cancers10070240

3. Guinan, M.; Benckendorff, C.; Smith, M.; Miller, G. J. Molecules 2020, 25, 2050. https://doi.org/10.3390/molecules25092050

4. Tino, J. A. ; Clark, J. M.; Field, A. K.; Jacobs, G. A.; Li, K. A.; Michalik, T. L.; Mcgeever-rubin, B.; Slusarchyk, W. A.; Spergel, S. H.; Sundeen, J. E.; Tuomari, A. V.; Weaver, E. R.; Young, M. G.; Zahler, R. J. Med. Chem. 1993, 36, 1221-1229.

https://doi.org/10.1021/jm00061a013

5. Soike, K. F.; Huang, J. L.; Russel, J. W.; Whiterock, V. J.; Sundeen, J. E.; Stratton, L. W.; Clarkm, J. M. Antiviral Res. 1994, 23, 219-224. https://doi.org/10.1016/0166-3542(94)90019-1

6. Wang, J.; Rawal, R. K.; Chu, C. K. In Medicinal Chemistry of Nucleic Acids Zhang, L.-H., Xi, Z., Chattopadhyaya, J. Eds.; John Wiley \& Sons, Inc ; Hoboken, NJ, 2011; pp 1-100.

7. Crimmins, M. T.; Tetrahedron 1998, 54, 9229-9272. https://doi.org/10.1016/S0040-4020(98)00320-2

8. Xie, M. S.; Niu, H. Y.; Qu, G. R.; Guo, H. M. Tetrahedron Lett. 2014, 55, 7156-7166. https://doi.org/10.1016/i.tetlet.2014.11.060

9. Mitsunobu, O.; Yamada, M.; Bull. Chem. Soc. Jpn. 1967, 40, 2380-2382. https://doi.org/10.1246/bcsj.40.2380

10. Swamy, K. C. K.; Kumar, N. N. B.; Balaraman, E.; Kumar, K. V. P. P. Chem. Rev. 2009, 109, 2551-2651 https://doi.org/10.1021/cr800278z

11. Fletcher, S. Org. Chem. Front. 2015, 2, 739-752. https://doi.org/10.1039/C5Q000016E

12. Li, J. J. Name Reactions, 2nd Edn., Springer-Verlag, Heidelberg, 2003, p 265. 
https://doi.org/10.1007/978-3-662-05336-2 198

13. But, T. Y. S., Toy, P. H. J. Am. Chem. Soc. 2006, 128, 9636-9637.

https://doi.org/10.1021/ja063141v

14. But, T. Y. S. ; Lu, J. ; Toy, P. H. Synlett 2010, 1115-1117.

https://doi.org/10.1055/s-0029-1219795

15. Hirose,D. ; Taniguchi, T., Ishibashi, H. Angew. Chem. Int. Ed. 2013, 52, 4613 - 4617.

https://doi.org/10.1002/anie.201300153

16. Hirose,D. ; Gazvoda, M. ; Janez Kosmrlj, J. ; Taniguchi, T. Chem. Sci. 2016, 7, 5148-5159. https://doi.org/10.1039/C6SC00308G

17. Buonomo, J. A.; Aldrich, C. C. Angew. Chem. Int. Ed. 2015, 54, 13041-13044. https://doi.org/10.1002/anie.201506263

18. Hirose,D. ; Gazvoda, M. ; Janez Kosmrlj, J. ; Taniguchi, T. Org. Lett. 2016, 18, 4036-4039. https://doi.org/10.1021/acs.orglett.6b01894

19. Beddoe,R. H.; Andrews, H. G.; Magné, V.; Cuthbertson, J. D.; Shannon-Little, A. L.; Shanahan, S. E.; Sneddon, H. F.; Denton, R. M. Science, 2019, 365(6456), 910-914.

https://doi.org/10.1126/science.aax3353

20. Tănase, C. I.; Drăghici, C.; Hanganu, A.; Pintilie, L.; Maganu, M.; Volobueva, A.; Sinegubova, E.; Zarubaev, V. V.; Neyts, J.; Jochmans, D.; Slita, A. V. Molecules 2019, 24, 2446.

https://doi.org/10.3390/molecules24132446

21. Gioti, E. G.; Koftis, T. V.; Neokosmidis, E.; Vastardi, E.; Kotoulas, S. S.; Trakossas, S.; Tsatsas, T.;

Anagnostaki, E. E.; Panagiotidis, T. D.; Zacharis, C.; Tolika, E. P.; Varvogli, A. A.; Andreou T.; Gallos, J. K.

Tetrahedron 2018, 74, 519-527.

https://doi.org/10.1016/i.tet.2017.12.034

22. Velasco, J.; Ariza, X.; Badía, L.; Bartra, M.; Berenguer, R.; Farrás, J.; Gallardo, J.; Garcia, J.; Gasanz, Y. J. Org. Chem. 2013, 78, 5482-5491.

https://doi.org/10.1021/j0400607v

23. Xu, H.; Wang, F.; Xue, W.; Zheng, Y.; Wang, Q.; Qiu, F. G.; Jin, Y. Org. Process Res. Dev. 2018, 22, 377-384. https://doi.org/10.1021/acs.oprd.8b00007

24. Beddoe R. H.; Sneddon, H. F.; Denton, R. M.; Org. Biomol. Chem. 2018, 16, 7774-7781. https://doi.org/10.1039/C8OB01929K

25. Ludek, O. R.; Krämer, T.; Balzarini, J.; Meier, C. Synthesis 2005, 8, 1313-1324.

26. Manvar, A.; Shah, A.; Tetrahedron 2013, 69, 680-691.

https://doi.org/10.1016/i.tet.2012.10.079

27. Guo, H. M.; Wu, Y. Y.; Niu, H. Y.; Wang, D. C.; Qu, G. R. J. Org. Chem. 2010, 75, 3863-3866. https://doi.org/10.1021/jo100397a

28. Klejch, T.; Pohl, R.; Janeba, Z.; Sun, M.; Keough, D. T.; Guddat, L. W.; Hocková, D.; Tetrahedron 2018, 74, 5886-5897.

https://doi.org/10.1016/i.tet.2018.08.014

29. Weising, S.; Torquati, I.; Meier, C. Synthesis 2018, 50, 1264-1274.

https://doi.org/10.1055/s-0036-1591732

30. Jessel, S.; Meier, C. Eur. J. Org. Chem. 2011, 2011, 1702-1713.

https://doi.org/10.1002/ejoc.201001473

31. Lu W.; Sengupta, S.; Petersen, J. L.; Akhmedov, N. G.; Shi, X. J. Org. Chem. 2007, 72, 5012-5015. https://doi.org/10.1021/jo070515+ 
32. Dai, L. Y.; Shi, Q. L.; Zhang, J.; Wang, X. Z.; Chen, Y. Q. J. Zhejiang Univ. Sci A 2013, 14(10), 760-766. https://doi.org/10.1631/jzus.A1300238

33. Fletcher, S.; Shahani, V. M.; Lough, A. J., Gunning, P. T. Tetrahedron 2010, 66, 4621-4632. https://doi.org/10.1016/i.tet.2010.03.118

34. Wamberg, M. C.; Pedersen, P. L.; Löffler, P. M. H.; Albertsen, A. N.; Maurer, S. E.; Nielsen, K. A.; Monnard, P. A. Bioconjug. Chem. 2017, 28, 1893-1905. https://doi.org/10.1021/acs.bioconjchem.7b00228

35. Šála, M.; De Palma, A. M.; Hřebabecký, H.; Nencka, R.; Dračínský, M., Leyssen, P.; Neyts, J.; Holý, A. Bioorg. Med. Chem. 2010, 18, 4374-4384. https://doi.org/10.1016/j.bmc.2010.04.081

36. Chen, W.; Flavin; M. T.; Filler, R.; Xu; Z. Q. J. Chem. Soc., Perkin Trans. 1 1998, 23, 3979-3988. https://doi.org/10.1039/a805929b

37. Brémond, P.; Audran, G.; Monti, H.; De Clarcq, E. Synthesis 2008, 20, 3253-3260. https://doi.org/10.1055/s-0028-1083146

38. Kasula, M.; Toyama, M.; Samunuri, R.; Rozy, F.; Yadav, M.; Bal, C.; Kumar, A.; Baba, M.; Sharon, A. Bioorg. Med. Chem. Lett. 2016, 26, 3945-3949. https://doi.org/10.1016/j.bmcl.2016.07.005

39. Rosen, T. C.; De Clercq, E.; Baizarini, J.; Haufe, G.; Org. Biomol. Chem. 2004, 2, 229-237. https://doi.org/10.1039/b310059f

40. Yin, X.; Li. W.; Schneller, S. W. Tetrahedron Lett. 2006, 47, 9187-9189. https://doi.org/10.1016/j.tetlet.2006.10.126

41. Fernández, P.; García-Mera, X.; López, C.; Morales, M.; Rodríguez-Borges, E. Synthesis 2005, 20, 3549-3554. https://doi.org/10.1055/s-2005-918420

42. Bazile, Q.; Serbessa, T.; Zhong, J. Tetrahedron Lett. 2012, 53, 1435-1437. https://doi.org/10.1016/i.tetlet.2012.01.047

43. Danappe, S.; Pal, A.; Alexandre, C.; Aubertin, A. Tetrahedron 2005, 61, 5782-5787. https://doi.org/10.1016/i.tet.2005.04.023

44. Liao, X.; Butora, G.; Olsen, D. B.; Carroll, S. S.; McMaster, D. R.; Leone, J. F.; Stahlhut, M.; Doss, G. A.; Yang, L.; MacCoss, M. Tetrahedron Lett. 2008, 49, 4149-4152.

https://doi.org/10.1016/i.tetlet.2008.04.115

45. Kumamoto, H.; Haraguchi, K.; Ida, M.; Nakamura, K. T.; Kitagawa, Y.; Hamasaki, T.; Baba, M.; Simbara, S.; Tanaka, H. Tetrahedron 2009, 65, 7630-7637

46. Viña, D.; Santana, L.; Uriarte, E.; Terán, C. Tetrahedron 2005, 61, 473-478. https://doi.org/10.1016/i.tet.2004.10.076

47. Aubin, Y.; Audran, G.; Monti, H.; De Clercq, E.; Bioorg. Med. Chem. 2008, 16, 374-381. https://doi.org/10.1016/j.bmc.2007.09.030

48. Kumamoto, H.; Deguchi, K.; Wagata, T.; Furuya, Y.; Odanaka, Y.; Kitade, Y.; Tanaka, H. Tetrahedron 2009, 65, 8007-8013. https://doi.org/10.1016/i.tet.2009.07.039

49. Jha, A. K.; Sharon, A.; Rondla, R.; Chu, C. K. Tetrahedron 2009, 65, 9362-9367. https://doi.org/10.1016/i.tet.2009.08.087

50. Eid, A. A.; Koubeissi, A.; Bou-Mjahed, R.; Al Khalil, N.; Farah, M.; Maalouf, R.; Nasser, N.; Bouhadir, K. H. Bioorg. Med. Chem Lett. 2013, 23, 174-178. https://doi.org/10.1016/j.bmcl.2012.10.122 
51. Chen, C.; Ye, W.; Liu, C.; Schneller, S. W. Tetrahedron 2012, 68, 3908-3914. https://doi.org/10.1016/i.tet.2012.03.023

52. Gouault-Bironneau, S.; Sène, A.; Catel, J. M.; Lequeaux, T. J. Fluor. Chem. 2008, 129, 848-851. https://doi.org/10.1016/i.jfluchem.2008.04.005

53. Singh, U. S.; Mishra, R. C.; Shankar, R.; Chu, C. K.; J. Org. Chem. 2014, 79, 3917-3923. https://doi.org/10.1021/jo500382v

54. Douadi A.; Brémond, P.; Lanez, T.; Pannecouque C.; Audran, G. Synlett 2011, 1, 111-115.

55. Christian, P.; Uttaro, J.; Broussous, S.; Math, C.; Périgaud, C. Tetrahedron 2013, 69, 2131-2136. https://doi.org/10.1016/i.tet.2013.01.011

56. Yang, Y.; Zheng, F.; Qing, F.; Tetrahedron 2011, 67, 3388-3394. https://doi.org/10.1016/i.tet.2011.03.054

57. Yoshimura, Y.; Asumi, K.; Matsui, H.; Tanaka, H. Org. Lett. 2006, 8, 6015-6018. https://doi.org/10.1021/ol062491j

58. Yoshimura, Y.; Asumi, K.; Imamichi, T.; Okuda, T.; Shiraki, K.; Takahata, H. J. Org. Chem. 2010, 75, 41614171.

https://doi.org/10.1021/jo100556u

59. Csuk, R.; Thiedee, G. Tetrahedron 1999, 55, 739-750. https://doi.org/10.1016/S0040-4020(98)01067-9

60. Franzyk, H.; Stermitz, F. R. J. Nat. Prod. 1999, 62, 1646-1654. https://doi.org/10.1021/np990288+

61. Wang, J.; Viña, D.; Busson, R.; Herdewijn, P. J. Org. Chem. 2003, 68, 4499-4505. https://doi.org/10.1021/jo0300946

62. Danappe, S.; Boeda, R.; Alexandre, C.; Aubertin, A. M.; Bourgoungnon, N.; Huet, F. Synth. Commun. 2006, 36, 3225-3239.

https://doi.org/10.1080/00397910600908918

63. Michael, B. Y.; Strazewski, P. Chem. Eur. J. 2009, 15, 6244-6257. https://doi.org/10.1002/chem.200802629

64. Liu, C.; Chen, Q.; Schneller, S. W.; Tetrahedron Lett. 2011, 52, 4931-4933. https://doi.org/10.1016/j.tetlet.2011.07.059

65. Mohamed, B. S.; Périgaud, C.; Peyrottes, S.; Uttaro, J.; Mathé, C. New J. Chem. 2018, 42, 974-979. https://doi.org/10.1039/C7NJ03991C

66. Miralles-Llumà, R.; Figueras, A.; Busqué, F.; Alvarez-Larena, A.; Balzarini, J.; Figueredo, M.; Font. J.; Alibés, R.; Maréchal, J. Eur. J. Org. Chem. 2013, 2013, 7761-7775.

https://doi.org/10.1002/ejoc.201301097

67. Weising, S.; Sterreberg, V.; Schols, D.; Meier, C. ChemMedChem 2018, 13, 1771-1778. https://doi.org/10.1002/cmdc.201800361

68. Kim, K.; Punna, V.; Karri, P.; Krishnamurthy, R. Beilstein J. Org. Chem. 2014, 10, 2131-2138. https://doi.org/10.3762/bjoc.10.220

69. Hollenstein, M.; Leumann, C. J. J. Org. Chem. 2005, 70, 3205-3217. https://doi.org/10.1021/jo047753e

70. Reichardt, B.; Meier, C. Nucleosides Nucleotides and Nucleic Acids 2007, 26, 935-937. https://doi.org/10.1080/15257770701507937

71. Kumamoto, H.; Takahashi, N.; Shimamura, T.; Tanaka, H.; Nakamura, K. T.; Hamasaki, T.; Baba, M.; Abe, H.; Yano, M.; Kato, N. Tetrahedron 2008, 64, 1494-1505. 
https://doi.org/10.1016/i.tet.2007.11.038

72. Mohamed, B. S.; Périgaud, C.; Mathé, C. Beilstein J. Org. Chem. 2017, 13, 251-256.

https://doi.org/10.3762/bjoc.13.28

73. Bera, S.; Nair, V. Helv. Chim. Acta 2000, 83, 1398-1407.

https://doi.org/10.1002/1522-2675(20000705)83:7<1398::AID-HLCA1398>3.0.CO;2-I

74. Pradère, U.; Roy, V.; Montagu, A.; Sari, O.; Hamada, M.; Balzarini; J.; Snoeck, R.; Andrei, G.; Agrofoglio, L. A. Eur. J. Med. Chem. 2012, 57, 126-133.

https://doi.org/10.1016/i.ejmech.2012.08.042

75. Fletcher, S.; Shahani, V. M.; Gunning, P. T. Tetrahedron Lett. 2009, 50, 4258-4261.

https://doi.org/10.1016/i.tetlet.2009.04.137

76. Fletcher, S. Tetrahedron Lett. 2010, 51, 2948-2950.

https://doi.org/10.1016/i.tetlet.2010.03.103

77. Alexander, P.; Krishnamurthy, V.; Prisbe, E. J. J. Med. Chem. 1996, 39, 1321-1330. https://doi.org/10.1021/jm950788+

78. John, J.; Kim, Y., Bennet, N.; Das, K.; Liekens, S.; Naesens, L.; Arnold, E.; Maguire, A. R.; Götte, M.; Dehaen, W.; Balzarini, J. J. Med. Chem. 2015, 58, 8110-8127.

https://doi.org/10.1021/acs.jmedchem.5b01180

79. Batista, D.; Schwarz, S.; Loesche, A.; Csuk, R.; Costa, P. J.; Oliveira, M. C.; Xavier, N. M. Pure Appl. Chem. 2016, 88, 363-379.

https://doi.org/10.1515/pac-2016-0102

80. Xavier, N. M.; de Sousa; E. C.; Pereira, M. P.; Loesche, A.; Serbian, I.; Csuk, R.; Conceição, M.

Pharmaceuticals 2019, 12, 103.

https://doi.org/10.3390/ph12030103

81. Leung, L. M. H.; Gibson, V.; Linclau, B. J. Org. Chem. 2008, 73, 9197-9206. https://doi.org/10.1021/jo801848h

82. Elhalem E.; Pujol, C. A.; Damonte, E. B.; Rodriguez, J. B. Tetrahedron 2010, 66, 3332-3340. https://doi.org/10.1016/i.tet.2010.02.092

83. Kumamoto, H.; Kobayashi, M.; Kato, N.; Balzarini, J.; Tanaka, H. Eur. J. Org. Chem. 2011, 2011, $2685-2691$. https://doi.org/10.1002/ejoc.201100062

84. Mahler, M.; Reichardt, B.; Hartjen, P.; van Lunzen, J.; Meier, C. Chem. Eur. J. 2012, 18, 11046-11062. https://doi.org/10.1002/chem.201200733

85. Tosh, D. K.; Crane, S.; Chen, Z.; Paoletta, S.; Gao, Z. G.; Gizewski, E.; Auchampach, J. A.; Salvemini, D.; Jacobson, K. A. ACS Med. Chem. Lett. 2015, 6, 804-808.

https://doi.org/10.1021/acsmedchemlett.5b00150

86. Yang, M.; Zhou, J.; Schneller, S. W. Tetrahedron Lett. 2004, 45, 8981-8982. https://doi.org/10.1016/j.tetlet.2004.10.052

87. Yang, M.; Zhou, J.; Schneller, S. W. Tetrahedron 2006, 62, 1295-1300. https://doi.org/10.1016/i.tet.2005.10.052

88. Chen, Q.; Liu; C.; Komazin, G.; Bowlin, T. L.; Schneller, S. W. Bioorg. Med. Chem. 2014, 22, 6961-6964. https://doi.org/10.1016/j.bmc.2014.10.014

89. Jin, Y. H.; Liu, P.; Wang, J.; Baker, R.; Huggins, J.; Chu, C. K.; J. Org. Chem. 2003, 68, 9012-9018. https://doi.org/10.1021/jo034999v

90. Gonçalves-Pereira, R.; Pereira, M. P.; Serra, S. G.; Loesche, A.; Csuk, R.; Silvestre, S.; Costa, P. J.; Oliveira, M. C.; Xavier, N. M. Eur. J. Org. Chem. 2018, 2018, 2667-2681. 


\section{Authors' Biography}

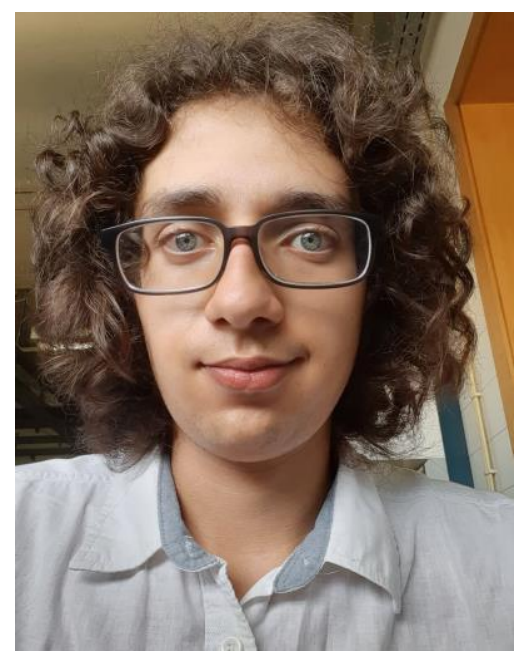

Eduardo C. de Sousa was born in Torres Vedras, Portugal, in 1997, and started his higher education in Lisbon, receiving his BSc degree in Chemistry in 2018 from Faculdade de Ciências, Universidade de Lisboa (CiênciasUL) with the graduation project on the synthesis of novel isonucleos(t)ides, receiving the final mark of 20/20, under supervision of Dr. Nuno Xavier, which results were published in Pharmaceuticals in 2019. He is currently finishing his MSc dissertation at the Carbohydrate Chemistry Group, Centro de Química Estrutural (CQE), under the supervision of Prof. Amélia Pilar Rauter, which included a six month internship at Max Plank Institute of Colloids and Interfaces, Biomolecular Systems Department, supervised by Dr. Daniel Varon Silva. His main research interest is carbohydrate synthetic chemistry.

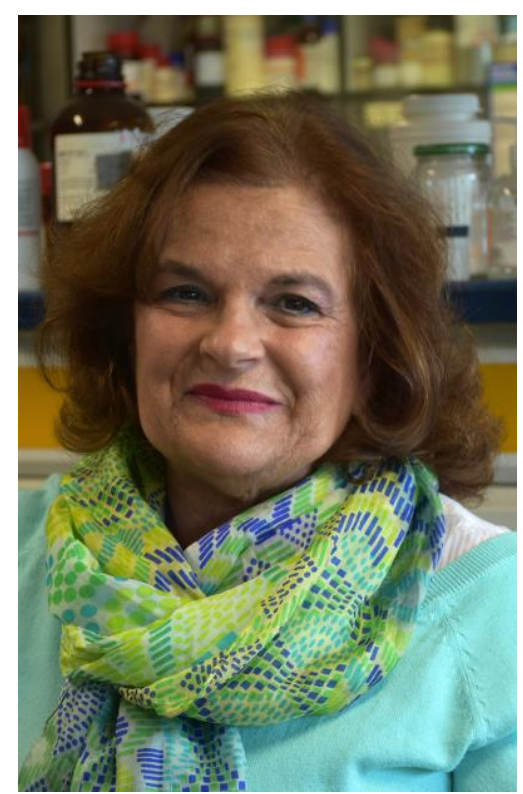

Amélia Pilar Rauter is Full Professor of Organic Chemistry, Department of Chemistry and Biochemistry, at Faculdade de Ciências, Universidade de Lisboa (CiênciasUL) (recently retired). She is the President of the International Carbohydrate Organisation and the Secretary of the European Carbohydrate Organisation, and serves IUPAC as Vice-President of the IUPAC Division on Organic and Biomolecular Chemistry, as Titular 
Member of IUPAC Division of Chemical Nomenclature and Structure Representation, and as Associate Member of its Interdivisional Committee on Terminology, Nomenclature and Symbols. She is the founder of the Portuguese Chemical Society Carbohydrate Chemistry Group, and the founder and leader of the Centro de Química Estrutural (CQE) Carbohydrate Chemistry Group. Her research covers the design and synthesis of new leads for diabetes, degenerative diseases (Alzheimer's and Prion diseases, cancer), and infection. Among her honors, she was awarded with the Madinaveitia-Lourenço Prize by the Spanish Royal Chemical Society, is Fellow of the Royal Society of Chemistry, and Chemistry Europe Fellow. At the national level she was awarded with the Mention of Excellency in all curricular evaluations since 2007 by CiênciasUL. 